\title{
Connexin 43 hemichannels contribute to the propagation of apoptotic cell death in a rat $\mathrm{C} 6$ glioma cell model
}

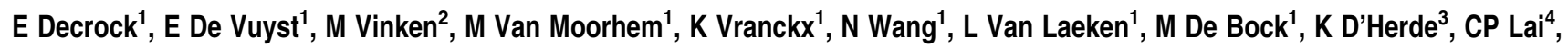 \\ V Rogiers ${ }^{2}$, WH Evans ${ }^{5}$, CC Naus ${ }^{4}$ and L Leybaert ${ }^{\star, 1}$
}

Gap junctions (GJs) have been demonstrated to communicate cell death signals from apoptotic to healthy cells, thereby spatially extending apoptosis. Before being incorporated into GJs, hemichannels (hemi-GJs) are normally closed but recent evidence suggests that they can be opened by various messengers and conditions, thereby forming a pore through which molecules can enter or leave the cell potentially leading to cell death. The aim of this study was to determine the contribution of GJs and hemichannels in the communication of apoptosis toward surrounding cells. We induced apoptosis in $\mathrm{C} 6$ glioma cells stably transfected with connexin (Cx)43, with cytochrome $C$ (cytC) using in situ electroporation and found that healthy surrounding cells underwent apoptotic transformation. Work with various cell death markers, wild-type (WT) and Cx43-expressing cells, inhibitors of GJs and/or hemichannels, and Cx43 gene silencing showed that GJs contribute to the spread of apoptosis in a zone next to where apoptosis was triggered whereas hemichannels also promoted cell death beyond this area. Buffering cytoplasmic $\mathrm{Ca}^{2+}$ changes inhibited the spread of apoptosis in both cases. We conclude that $\mathrm{Cx} 43$ hemichannels, in concert with their GJ counterparts, play a role in communicating cyt $C$-induced apoptotic cell death messages.

Cell Death and Differentiation (2009) 16, 151-163; doi:10.1038/cdd.2008.138; published online 26 September 2008

Gap junctions (GJs), that is channels that connect the cytoplasm of neighboring cells, have been well documented to play a role in the communication of cell death messages between cells, in particular in the context of apoptotic cell death. ${ }^{1-4}$ They are formed by two hemichannels (connexons) that interact and open to form a conduit for the passage of substances below $1-1.5 \mathrm{kDa}$. The building blocks of these channels are the transmembrane spanning connexin $(\mathrm{Cx})$ proteins, named according to their corresponding molecular weight, with $\mathrm{Cx} 43$ as the most abundant and widespread $\mathrm{Cx}$ in the human body. ${ }^{5}$ Before being incorporated into GJs, hemichannels transiently reside in the plasma membrane in a closed state. Recent studies, in astrocytes as well as in other cell types, have demonstrated that hemichannels may open in response to various triggers. ${ }^{5}$ The list of conditions and intracellular signals triggering hemichannel opening and consecutive messenger release is extensive and includes depolarization of the membrane potential, ${ }^{6}$ reactive oxygen species, ${ }^{6}$ redox status, ${ }^{7}$ phosphorylation status, ${ }^{8}$ cytoplasmic
$\mathrm{Ca}^{2+}$ changes, ${ }^{9}$ a decrease of extracellular $\mathrm{Ca}^{2+},{ }^{10}$ mechanical stimulation, ${ }^{11}$ ischemia/hypoxia ${ }^{12,13}$ and also certain Cx mutations. ${ }^{14}$ As many of these factors clearly link to the conditions and signals involved in apoptosis, hemichannels may contribute to cell death for example by forming a pore that allows the release of essential metabolites and the uptake of $\mathrm{Na}^{+}, \mathrm{Ca}^{2+}$ and other potentially toxic substances. ${ }^{13,15-18}$ In this manner, Cx hemichannels could have an influence on the progression of the cell death process as has been documented in HeLa cells transfected with $\mathrm{Cx} 43$ exposed to various apoptotic agents ${ }^{15}$ and to trigger apoptosis in Marshall and L2 lung epithelial cells in response to oxidative cell stress. ${ }^{6}$ In addition, they are the essential transducers of the antiapoptotic effects of bisphosphonates, drugs used in the treatment of bone diseases, and may thus promote cell survival as well. ${ }^{19}$

Next to being involved in the complex cascade leading to apoptosis, hemichannels may, like GJs, play a role in the communication of cell death messages between cells. They have been shown to release molecules such as adenosine

\footnotetext{
${ }^{1}$ Department of Basic Medical Sciences - Physiology group, Faculty of Medicine and Health Sciences, Ghent University, Ghent, Belgium; ${ }^{2}$ Department of Toxicology, Faculty of Medicine and Pharmacy, Vrije Universiteit Brussel (VUB), Brussels, Belgium; ${ }^{3}$ Department of Basic Medical Sciences - Anatomy and Embryology group, Faculty of Medicine and Health Sciences, Ghent University, Ghent, Belgium; ${ }^{4}$ Department of Cellular and Physiological Sciences, Faculty of Medicine, University of British Columbia, Vancouver, British Columbia, Canada and ${ }^{5}$ Department of Medical Biochemistry and Immunology, Cardiff University School of Medicine, Cardiff, UK ${ }^{*}$ Corresponding author: L Leybaert, Department of Basic Medical Sciences - Physiology group, Ghent University, De Pintelaan 185 (Block B, Rm 310 ), B-9000 Ghent. Belgium. Tel: + 32933233 66; Fax: + 32933230 59; E-mail: Luc.Leybaert@UGent.be

Keywords: apoptosis; connexins; connexons; gap junctions; hemi-gap junctions; cytoplasmic calcium

Abbreviations: 6-CF, 6-carboxyfluorescein; Al, apoptotic index; ATP, adenosine triphosphate; BAPTA-AM, 1,2-bis(2-aminophenoxy)ethane- $N, N, N^{\prime}, N^{\prime}$-tetraacetic acid acetoxymethyl ester; Cbx, carbenoxolone; CFDA-AM, carboxyfluorescein diacetate acetoxymethylester; Cx, connexin; cyt $C$, cytochrome C; DAPI, $2^{\prime}, 6^{\prime}$-diamidino2-phenylindole; DF, divalent-free; DTR, dextran Texas Red; EtBr, ethidium bromide; FBS, fetal bovine serum; FRAP, fluorescence recovery after photobleaching; GAPDH, Glyceraldehyde 3-phosphate dehydrogenase; GJ, gap junction; HBSS, Hank's balanced salt solution; HEK, human embryonic kidney; IP 3 , inositol trisphosphate; $\mathrm{NAD}^{+}$, nicotinamide adenine dinucleotide; Panx, pannexin; PBSD + , phosphate-buffered saline supplemented with $\mathrm{Ca}^{2+}$ and $\mathrm{Mg}^{2+}$; $\mathrm{PFA}$ paraformaldehyde; PI, propidium iodide; SLDT, scrape loading and dye transfer; WT, wild-type
}

Received 29.2.08; revised 15.7.08; accepted 13.8.08; Edited by JA Cidlowski; published online 26.9.08 
triphosphate (ATP), glutamate, nicotinamide adenine dinucleotide $\left(\mathrm{NAD}^{+}\right)$, prostaglandins and glutathione. $5,11,16,18,20$ These substances may act in a paracrine manner on surrounding cells thereby modulating the spatial spreading of the cell death process. ${ }^{17}$

The aim of this study was to investigate the role of both Cx channels in the communication of apoptotic signals to surrounding cells. We triggered apoptosis by loading the cells using in situ electroporation with cytochrome $C$ (cyt $C$ ), a signaling agent located far downstream in the intrinsic apoptotic pathway, ${ }^{21}$ thereby avoiding upstream signaling events that may complicate the picture. Earlier studies with cyt $C$-triggered apoptosis provided evidence for a role of direct cell-to-cell communication through GJs in the spread of cell death, ${ }^{1,22-24}$ but none of these studies have focussed on the role of hemichannels in the communication of cell death. Our data obtained in $\mathrm{C} 6$ glioma cells stably transfected with $\mathrm{Cx} 43$ (C6Cx43), using various $\mathrm{Cx}$ channel-inhibiting approaches including post-transcriptional Cx43 gene silencing, suggest that GJs contribute to the spread of apoptosis to directly neighboring bystander cells whereas hemichannels promote apoptosis in regions located as far as several $100 \mu \mathrm{m}$ away from the initial cyt $C$-loaded cell zone.

\section{Results}

Electroporation loading of cyt $\mathbf{C}$ in $\mathbf{C} \mathbf{6}$ glioma cells. In situ electroporation with bipolar $50 \mathrm{kHz}$ pulses was used to load adherent $\mathrm{C} 6$ glioma cells with the apoptotic agent cyt $C$. Earlier work has demonstrated that this technique can be applied to load a small strip of cells with high efficiency and minimal cell death. ${ }^{25}$ C6WT and C6Cx43 cultures were electroporated with cytC $(100 \mu \mathrm{M})$ together with the $10 \mathrm{kDa}$ DTR $(100 \mu \mathrm{M})$ to identify the area of cyt $C$-loaded cells - both probes have comparable molecular weights $(12.4 \mathrm{kDa}$ for cyt $C$ ). Labeling with an antibody directed against horse cyt $C$, which does not recognize the endogenous rat variant, demonstrated a good colocalization of the two probes in the cells in the electroporated area (Figure $1 \mathrm{a}$ and b). The zone of DTR/ cyt $C$-loaded cells was rectangular with a length of approximately $8 \mathrm{~mm}$ and a width of $296 \pm 7.1 \mu \mathrm{m}$ (full width at half-maximum $-n=7$ ) (Figure 1a). Within $15 \mathrm{~min}$ after electroporation, the cells in the cyt $C$-loaded zone showed morphological changes characteristic for apoptosis, such as cell rounding, cytoplasmic shrinkage and membrane blebbing - no such changes occurred when electroporation was performed with DTR-only. The cells in the cyt $C$-loaded area died quickly and detached upon washing during the staining procedures.

Spread of cyt $\boldsymbol{C}$-triggered apoptosis. We investigated the degree of apoptosis in areas next to the cyt $C$-loaded zone, to obtain information on the spread of apoptosis to healthy cells. To this purpose, we acquired images based on the absence of detectable DTR staining (Figure 1a, c and d), at various time points after cyt $C$ loading. Release of cyt $C$ from the mitochondria into the cytoplasm leads to the activation of cystein proteases, called caspases, that specifically cleave their substrate proteins after an aspartate residue. ${ }^{21}$
Activation of these enzymes was investigated with an FITC-VAD-FMK in situ marker. Experiments in C6Cx43 revealed the presence of caspase-positive cells that were DTR-negative in the non-loaded zone $6 \mathrm{~h}$ after cyt $C$ loading. The caspase staining appeared to be regionally different: a band of caspase-positive/DTR-negative cells was observed next to the cyt $C$-loaded zone whereas further away apoptotic cells appeared as clusters or single cells (Figure 1c and d). Averaging of multiple images acquired in 22 experiments allowed to extract a caspase staining profile in a direction away from the cyt $C$-loaded zone (Figure 1c). We determined the width of the band-like zone, which was in the order of $185 \mu \mathrm{m}$ at half-maximum. On the basis of this, we defined two zones outside the cyt $C$-loaded area for further analysis: area 1 from 0 to $200 \mu \mathrm{m}$ containing a streak of apoptotic cells and area 2 from 200 to $740 \mu \mathrm{m}$ with the clusters and individual caspase-positive cells (Figure 1c and d).

Experiments in $\mathrm{C} 6 \mathrm{Cx} 43$ showed that the $\mathrm{Al}$, as determined from caspase-positive counts in areas 1 and 2 , increased with time over the 6-h observation period following cyt $C$ loading (Figure $2 \mathrm{a}$ and $\mathrm{b}$ ). In area 2, the $\mathrm{Al}$ values were smaller (compare Figure $2 \mathrm{~b}$ and $\mathrm{a}$ ). Control experiments performed by loading the cells with vehicle containing DTR-only showed a flat curve with low values. In C6WT, the Al also increased with time in area 1 and to a lesser (non-significant) extent in area 2, presumably because of background $\mathrm{Cx} 43$ expression in these cells, as can be inferred from western blot analysis shown in Figure $3 \mathrm{a}$ and as reported by others. ${ }^{27}$ At $6 \mathrm{~h}$, the Als in $\mathrm{C6Cx} 43$ were significantly above the values observed in C6WT (Figure 2a and b). To validate the results obtained with caspase staining, we applied other apoptotic markers: phosphatidylserine flip-flop toward the outer plasma membrane leaflet with annexin V-FITC, internucleosomal DNA fragmentation/condensation with Hoechst 33342 staining, and the progression to secondary necrosis with subsequent loss of plasma membrane integrity by the uptake of EtBr. The results obtained with these markers were basically comparable with the observations performed with the caspase staining (Figure $2 c-h$ ). The Als were, however, lower than those based on active caspase staining, with annexin $V$, nuclear fragmentation/condensation and EtBr positivity giving progressively lower apoptotic counts, as expected when probing post-caspase activation events. ${ }^{21}$

Role of Cx43 hemichannels and GJ channels in the spread of cyt $C$-induced apoptosis. Both Cx43 GJs and their hemichannel parts may contribute to signaling from the apoptosis trigger zone to areas 1 and 2. However, $P_{2} X_{7}$ receptor pores and Panx channels also form a release pathway that should be distinguished from $\mathrm{Cx}$ hemichannels, ${ }^{28,29}$ and recent studies indicate a role for both channels/pores in the cell death process. ${ }^{12,29,30}$ We first set out to determine the involvement of these two alternative release pathways. Western blot analysis demonstrated the absence of $\mathrm{P}_{2} \mathrm{X}_{7}$ protein expression in C6WT and C6Cx43 (Figure 3b). Panx1, a major Panx that has been well characterized in terms of hemichannel properties, ${ }^{29}$ could not be detected at messenger level in RT-PCR experiments on C6WT and C6Cx43 cells (Figure 3c). Furthermore, experiments in C6 cells stably expressing Panx1-Myc ${ }^{31}$ (Cx43 background 


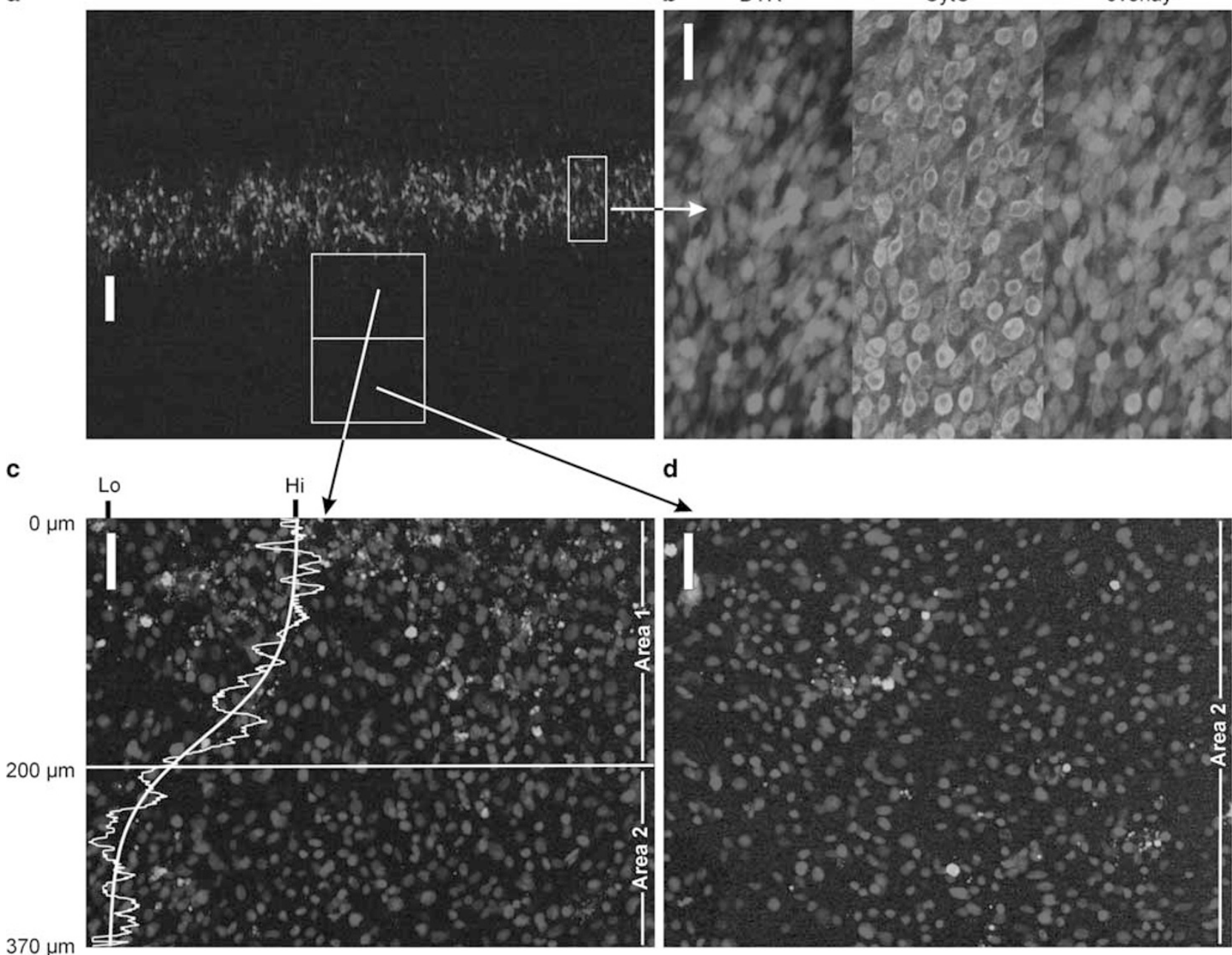

Figure 1 Electroporation loading with cyt $C$ and analysis of apoptotic cell death in remote non-cytC-loaded zones. (a) CytC-loaded cell zone in an adherent confluent C6Cx43 culture as judged from the DTR fluorescent reporter (red) included in the loading medium. The scale bar measures $200 \mu \mathrm{m}$. (b) Combined DTR staining (red) and cytC immunostaining (green) performed directly after loading. The first (left) part of the image is a DTR staining, the second a cytC immunostaining of the same region and the third one an overlay of both stainings. The DTR signal was more concentrated in the center of the cells and less visible at the borders of the loaded zone but in general, there was a good overlap between the two signals. The scale bar measures $50 \mu \mathrm{m}$. (c and d) Apoptotic cell death was investigated outside the cytC-loaded cell zone with various assays, including a CaspACE FITC-VAD-FMK In situ Marker illustrated here. Images were taken $6 \mathrm{~h}$ after cytC loading just outside the DTR-positive zone and in a second region, located one image height $(370 \mu \mathrm{m})$ further away, as indicated by the white rectangles on panel a. Caspase-positive cells (green - blue represents DAPI-positive nuclei) appeared as a band-like region close to the cytC-loaded zone (zone above the white horizontal line in $\mathbf{c}$ ) and appeared more dispersed (clusters and single cells) further away (lower part of $\mathbf{c}$ and $\mathbf{d}$ ). Averaging images from 22 experiments allowed to determine an intensity profile of caspase positivity, indicated as the white curve drawn on panel $\mathbf{c}$. The caspase signal was highest ( $\mathrm{Hi}$ - due to the many caspase-positive cells) close to the cytC-loaded zone and decreased to a lower level (Lo) further away (arbitrary fluorescent units). We defined analysis zone 'area 1' as a zone of $200 \mu \mathrm{m}$ image height demarcated by the white horizontal line on panel c (caspase signal reduced to $\sim 1 / 3$ ) and 'area 2' as the remainder of this image plus the image $370 \mu \mathrm{m}$ lower (panels $\mathrm{c}$ and d). Scale bars represent $50 \mu \mathrm{m}$

expression was comparable here with C6WT - data not shown) demonstrated apoptosis spread that was not different from that of C6WT $(9.9 \pm 1.2 \%$ in area 1 and $2.5 \pm 0.2 \%$ in area $26 \mathrm{~h}$ after cyt $C$ loading $(n=6)$ - compare with the values depicted in Figure $2 \mathrm{a}$ and $\mathrm{b}$ ).

To investigate the contribution of GJs and hemichannels, we applied several $\mathrm{Cx}$ channel inhibitor substances. Cbx $(25 \mu \mathrm{M})$, applied $15 \mathrm{~min}$ before cyt $C$ loading and also present in the culture medium thereafter $(15 \mathrm{~min}+6 \mathrm{~h})$, significantly reduced the $\mathrm{Al}$ determined from caspase stainings in $\mathrm{C} 6 \mathrm{C} \times 43$ at $6 \mathrm{~h}$ after cyt $C$ loading, in both areas 1 and 2 (Figure $4 \mathrm{a}$ and b). No significant effects were observed in C6WT.
Comparable results were obtained with annexin V-FITC marking (Figure $4 c$ and $d$ ). In the next step, we determined the effect of $\mathrm{Cbx}$ on GJ coupling studied with FRAP. Incubation with $\mathrm{Cbx}$ for $15 \mathrm{~min}$ or $15 \mathrm{~min}+6 \mathrm{~h}$ strongly depressed dye coupling in $\mathrm{C} 6 \mathrm{C} \times 43$ to the level observed in C6WT (Figure 4e). It is known from a structural analog of Cbx, $\alpha$-glycyrrhetinic acid, that its action may be weakened by the presence of serum. ${ }^{32}$ We repeated some experiments with SLDT, which allowed to perform Cbx incubations in the presence of serum (not possible with FRAP - see Materials and Methods). Under these conditions, inhibition by $\mathrm{Cbx}$ was less potent (inset to Figure $4 \mathrm{e}$ ). We further assessed the effect 

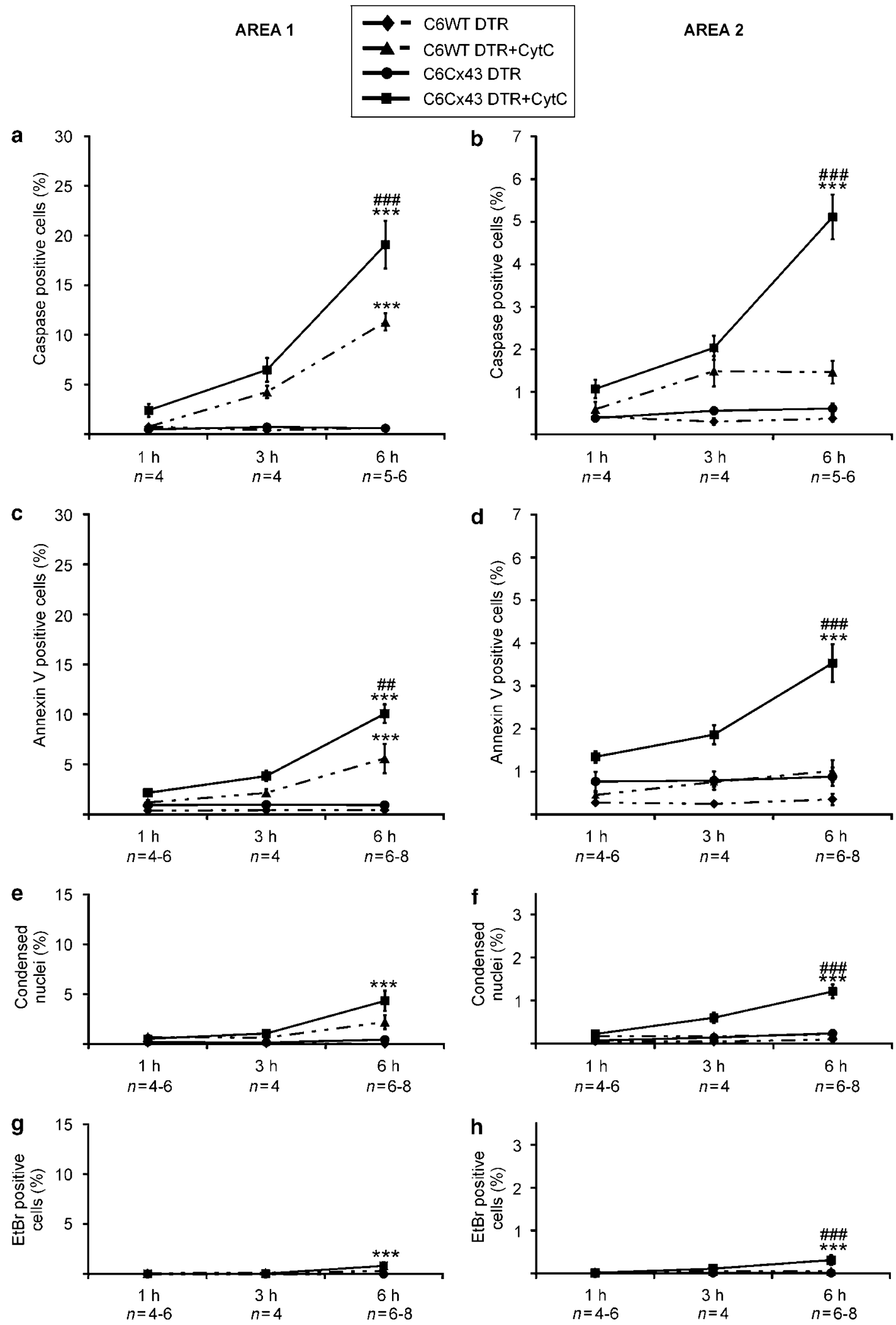

Figure 2 Spread of apoptosis in areas 1 and 2 at various time points after cytC loading. (a and $\mathbf{b}$ ) The $\mathrm{Al}$ (expressed as a percentage of caspase-positive cells) increased with time in areas 1 and 2 and was significantly higher in $\mathrm{C} 6 \mathrm{C} \times 43$ as compared with WT cells $6 \mathrm{~h}$ after cytC loading. Cultures loaded with DTR only showed a low Al and no further changes with time. (c-h) Very similar results were obtained with annexin V staining (c and $\mathbf{d})$, nuclei displaying DNA fragmentation/condensation (e and $\mathbf{f})$ and membrane permeability, estimated from EtBr uptake ( $\mathbf{g}$ and $\mathbf{h}$ ). Data represent mean \pm S.E.M. with ' $r$ ' given below the abcis; *significance compared to loading with DTR-only; "significance compared with the corresponding WT data 
a
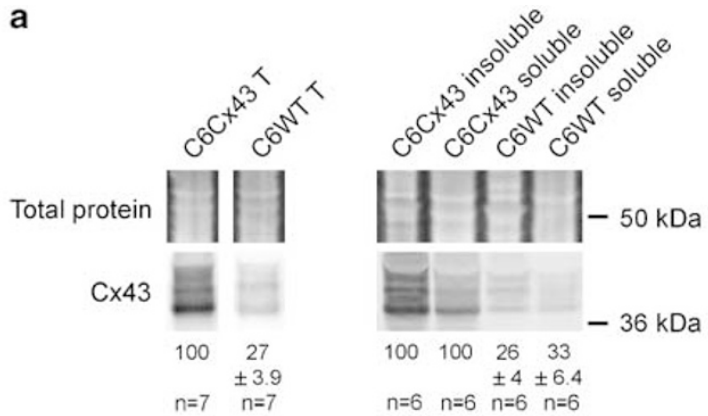

b

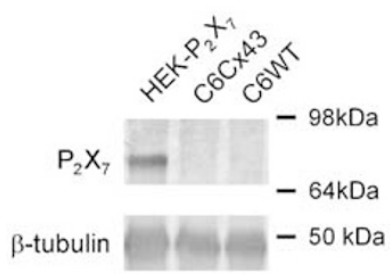

c

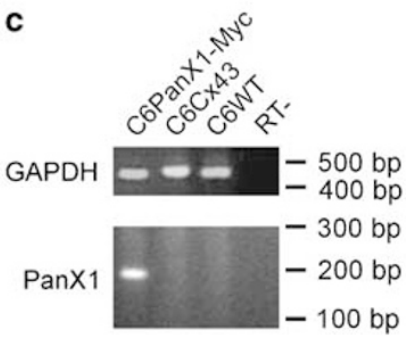

Figure 3 Western blot analysis for $\mathrm{Cx} 43$ and $\mathrm{P}_{2} \mathrm{X}_{7}$ and RT-PCR for Panx1. (a) Cx43 expression in total protein lysates $(T)$ and after separation of the Triton $X-100$ soluble and insoluble fractions, the latter representing the fraction incorporated into GJs. The percentage of $\mathrm{C} \times 43$ signal relative to $\mathrm{C} 6 \mathrm{C} \times 43$ is given as mean \pm S.E.M. (equal protein loading was verified with total protein staining). (b) The cell lines used showed no discernible expression of $\mathrm{P}_{2} \mathrm{X}_{7}$ receptor protein (HEK- $\mathrm{P}_{2} \mathrm{X}_{7}$ was used as a positive control - $\beta$-tubulin reports equal loading). (c) Panx1 was absent in C6C 43 and C6WT cells as demonstrated by RT-PCR (C6 Panx1-Myc represents a positive control and reverse transcriptase replaced with RNase/DNase-free water (RT-) a negative control - GAPDH is an internal control)

of $\mathrm{Cbx}$ on hemichannel responses, by studying ATP release triggered by exposure of the cells to DF cation conditions, a well-documented stimulus of $\mathrm{C} \times 43$ hemichannel opening. ${ }^{10}$ Cbx significantly inhibited DF-triggered ATP release in both short and long application schemes (Figure 4f).

We tested two peptides, Gap 26 and 27, that are identical to a short sequence on extracellular loops 1 and 2, respectively, of the Cx43 protein. Short (30 min) incubations with these peptides are sufficient to inhibit hemichannel-related responses, whereas longer exposures are needed to inhibit GJs. ${ }^{5,8,9}$ In line with this, Gap 26 or 27 applied 30 min or $30 \mathrm{~min}+6 \mathrm{~h}$ at $0.25 \mathrm{mg} / \mathrm{ml}$ ( $\sim 161$ and $\sim 192 \mu \mathrm{M}$, respectively) significantly reduced DF-triggered ATP release (Figure 4f) but did not affect GJ coupling (Figure 4e). By contrast, $24 \mathrm{~h}+6 \mathrm{~h}$ exposures to Gap 27 inhibited both DF-triggered ATP release and GJ coupling (Figure 4e and f). We tested these conditions on the Al in areas 1 and 2 . Preincubation of the cells with Gap 26 or 27,30 min before cyt $C$ loading, and subsequent inclusion of the peptide in the culture medium during the $6 \mathrm{~h}$ thereafter did not influence the caspase-based Al in area 1 but reduced it significantly in area 2 (Figure $4 \mathrm{a}$ and $\mathrm{b}$ ). Longer, $24 \mathrm{~h}$ preincubations with Gap 27 followed by $6 \mathrm{~h}$ incubation after cyt $C$ loading, a protocol that inhibits both GJs and hemichannel responses, significantly reduced the Al not only in area 2 but also in area 1 (Figure 4a and $b$ ).

To further substantiate the contribution of $\mathrm{Cx}$ channels, we performed experiments with post-transcriptional silencing of the Cx43 gene gja1 using siRNA. Treatment with siRNA directed against $\mathrm{Cx} 43$ significantly reduced the $\mathrm{C} \times 43$ protein expression by $\sim 35 \%$ compared with the negative control in the $\mathrm{C} 6 \mathrm{C} \times 43$ cell line. In C6WT, background $\mathrm{C} \times 43$ expression was suppressed by 43\% (Figure 5a). SLDT experiments in C6Cx43 cells demonstrated significant inhibition of GJs as compared with control conditions (Figure $5 b$ ). DF-triggered ATP release was also significantly depressed, with the responses appearing half-way between the negative control condition and C6WT (Figure 5c). At the level of cell death, we found that siRNA treatment significantly reduced the spread of apoptosis, based on caspase-positive counts, toward areas 1 and 2 in C6Cx43 cells (Figure $5 d$ and e). In C6WT cells, cell death also appeared to be lowered in the two zones compared with the negative control, but this effect did not attain statistical significance (Figure $5 d$ and e). The apoptosis spread remaining after siRNA treatment may be related to the presence of other Cxs such as $\mathrm{Cx} 26$ or $\mathrm{Cx} 32$, for which a faint background signal could be detected by RT-PCR (unpublished observation).

Figure 6 summarizes the effects of the various protocols used on GJ coupling, hemichannel-related ATP release and the $\mathrm{Al}$, and further presents correlation studies between the functional effects on dye coupling/ATP release and apoptosis in areas 1 and 2. The Pearson correlation coefficient and the significance level in Figure $6 \mathrm{~b}$ and $\mathrm{c}$ indicate a preferential contribution of GJs in apoptotic cell death in area 1. The relation between DF-triggered ATP release and Al was significant in both areas 1 and 2 (Figure $6 \mathrm{~d}$ and $e$ ).

Cell death messengers. Cytoplasmic $\mathrm{Ca}^{2+}$ is an important intracellular messenger with a prominent role in apoptotic signaling. ${ }^{33}$ In addition, cytoplasmic $\mathrm{Ca}^{2+}$ changes may be communicated through GJs by diffusion of the $\mathrm{Ca}^{2+}$ mobilizer inositol trisphosphate $\left(\mathrm{IP}_{3}\right)$ through the channels, ${ }^{34}$ and $\mathrm{Ca}^{2+}$ changes are known to trigger hemichannel opening, ${ }^{9}$ which may on its turn influence the cytoplasmic $\mathrm{Ca}^{2+}$ level as well. ${ }^{13}$ We tested the effect of buffering cytoplasmic $\mathrm{Ca}^{2+}$ changes by ester loading the $\mathrm{C} 6 \mathrm{Cx} 43$ cells with the $\mathrm{Ca}^{2+}$ chelator BAPTA-AM $(5 \mu \mathrm{M})$ applied $1 \mathrm{~h}$ before and also $6 \mathrm{~h}$ after cyt $C$ loading. This treatment significantly reduced the caspase-based $\mathrm{Al}$ in areas 1 and 2 (Figure $7 \mathrm{a}$ and b), pointing to an involvement of $\mathrm{Ca}^{2+}$ changes in the induction of apoptosis in both areas. BAPTA-AM loading did not influence GJ coupling but significantly reduced DF-triggered ATP release (Figure $7 \mathrm{c}$ and d), as observed in Cx32expressing cells. ${ }^{9}$ The effectiveness of $\mathrm{Ca}^{2+}$ buffering with BAPTA-AM was verified in test experiments with $\mathrm{Ca}^{2+}$ transients triggered by exposure of $\mathrm{C} 6 \mathrm{C} \times 43$ cells to $400 \mathrm{nM}$ ATP. Following $1 \mathrm{~h}$ BAPTA-AM loading (corresponding to the start of cyt $C$ loading), the amplitude of the transients was reduced to $27 \pm 9 \%(n=5)$ of their control amplitude $(P<0.001)$, whereas $1 \mathrm{~h}+6 \mathrm{~h}$ loading (end of the time window used for apoptosis detection) gave a reduction to $68 \pm 6 \%(n=5)$ of control $(P<0.05)$.

In terms of extracellular messengers, ATP is an important candidate that can be released through hemichannels. ${ }^{20,28}$ Measurements in the culture medium demonstrated significant ATP release that attained a maximum $2 \mathrm{~h}$ after cyt $C$ loading in $\mathrm{C} 6 \mathrm{Cx} 43$ whereas a flat trace was observed in 

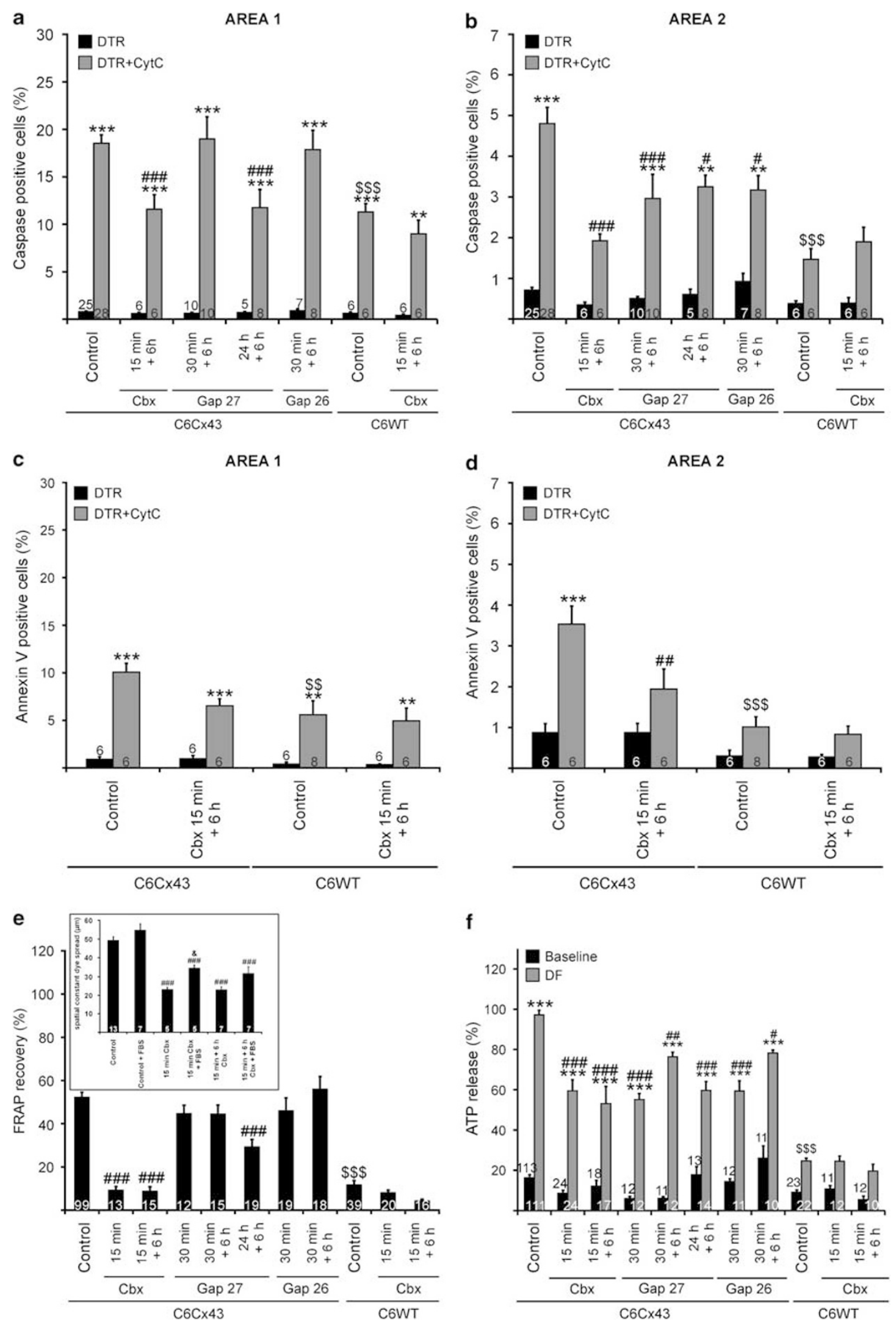
C6WT (Figure 8). The ATP peak was significantly (not fully) inhibited by treatment with siRNA directed against gja1. Inclusion of $10 \mathrm{U} / \mathrm{ml}$ of apyrase $\mathrm{VI}$ and VII in the culture medium during the $6 \mathrm{~h}$ period after cyt $C$ loading, to hydrolyze ATP to ADP and ADP to AMP respectively, did not significantly influence the caspase-based $\mathrm{Al}$ in areas 1 and $2(16.6 \pm 3.4 \%$ in area 1 compared with $17.5 \pm 2.6 \%$ for control and $6.5 \pm 1.9 \%$ in area 2 compared with $5.3 \pm 1.8 \%$ for control - Al $6 \mathrm{~h}$ after cyt $C$ loading, $n=6)$. In line with this, the exposure of $\mathrm{C} 6 \mathrm{Cx} 43$ cultures to $5 \mathrm{mM}$ ATP over $6 \mathrm{~h}$ did not significantly increase caspase-positive counts (data not shown). Glutamate is another messenger that can be released through hemichannels, ${ }^{18}$ but the inclusion of $5 \mathrm{mM}$ glutamate in the culture medium for $6 \mathrm{~h}$ did not induce apoptosis in $\mathrm{C} 6 \mathrm{C} \times 43$ as well (data not shown). We considered the possibility that a depletion of intracellular ATP was, as a sensitizer, at the basis of cell death in zone $2 .^{15}$ The intracellular ATP content was decreased $2 \mathrm{~h}$ after cyt $C$ loading and attained $85 \pm 1 \%(n=3)$ of the values measured in cultures loaded with DTR-only $(P<0.01)$. The cellular ATP content was thus slightly decreased at the time point of maximal ATP release, possibly contributing to cell death.

\section{Discussion}

This study demonstrates that triggering apoptosis with cyt $C$, in a delineated zone of confluent rat C6 glioma cells stably transfected with $\mathrm{Cx} 43$, results in cell death that spreads toward healthy neighboring cells. The appearance of apoptosis at distance was related to the presence of both GJs and hemichannels, as evidenced by comparison with WT variants, work with several GJ and/or hemichannel inhibitors and Cx43 gene silencing. Our data confirm that GJs may contribute to the spatial spread of apoptosis and point to a role of hemichannels in apoptosis beyond the zone where GJs contribute. Cytoplasmic $\mathrm{Ca}^{2+}$ appears to play a pivotal role in both signaling pathways.

Various techniques such as scrape loading and microinjection have been applied previously to investigate the role of GJs in the spread of cyt $C$-induced apoptosis, for example in retinal cells (endogenous Cxs), ${ }^{1}$ Xenopus oocytes (Cx38), ${ }^{22}$ baby hamster kidney cells $(\mathrm{C} \times 32)^{23}$ and a squamous head and neck carcinoma cell line $(\mathrm{Cx} 43) .{ }^{24}$ In this study, we used electroporation loading that was optimized to combine minimal cell death with good loading efficiency. ${ }^{25}$ We applied four different approaches to interfere with GJ and hemichannel functioning: comparison of Cx43-expressing and WT C6 cells, $\mathrm{Cx}$ channel blocking with $\mathrm{Cbx}$ or $\mathrm{Cx}$ mimetic peptides and siRNA directed against $\mathrm{Cx} 43$. Cbx is a well-known agent that blocks both GJs and hemichannels. The peptides Gap 26 and 27 were initially introduced to block GJs and were later found to inhibit hemichannel-related responses after short exposures (30 min). 5,8,9 Gap peptides have been demonstrated to interact with the extracellular loops of $\mathrm{Cx} 43,{ }^{35}$ to reduce $\mathrm{Cx} 43$ hemichannel currents, ${ }^{36}$ to block hemichannelrelated responses in various model systems $s^{8,9,11,37}$ and to have no effect in a scrambled version. ${ }^{37}$ To approach $\mathrm{Cx}$ channel inhibition from another side, we applied siRNA treatment directed against $\mathrm{Cx} 43$, which is considered as a strong criterion for the participation of hemichannels in cellular processes. $^{38}$

A major observation is the fact that blocking GJs and hemichannels with $\mathrm{Cbx}$, long incubation with Gap 27 $(24 h+6 h)$ or siRNA treatment all gave the same pattern of inhibition of apoptosis in areas 1 and 2. By contrast, short incubations with Gap 26 or 27 (30 min $+6 \mathrm{~h}$ ), inhibiting hemichannels only, resulted in a suppression of apoptosis solely in area 2 (Figure 6a). These data suggest the involvement of hemichannels in apoptosis in area 2, a zone starting $200 \mu \mathrm{m}$ away from the cyt $C$-loaded region. This is further supported by the correlation studies, demonstrating a significant correlation between hemichannel ATP release and apoptosis in area 2 (Figure 6e), but somewhat at odds with the significant correlation found between hemichannel ATP release and apoptosis in area 1 (Figure 6d). However, in area 1 , the correlation was stronger for apoptosis and GJ coupling (Figure 6b), suggesting a combined contribution of both channel types in area 1 but with dominance of GJs over hemichannels. An interesting experiment would consist of inhibiting GJs without influencing hemichannels but this kind of intervention is currently not possible.

Although the conclusion of a hemichannel component in the spread of cell death is an entirely new observation, the contribution of GJs is a well-established fact although still surrounded by some controversy because the apoptotic messengers are largely unknown and a 'good samaritan' role by passing cell survival factors between cells is also possible. ${ }^{3,4}$ We hypothesize that hemichannels can promote apoptosis in the presently used model in two different ways: first, by acting in apoptotic cells as a release pathway for messengers that diffuse extracellularly and induce apoptosis in surrounding healthy cells; second, by contributing in healthy cells as an entry route for proapoptotic messengers or as a leakage pore through which healthy cells lose essential metabolites. The current experimental model does not allow distinguishing between these two possibilities as the inhibition

\footnotetext{
Figure 4 Role of GJs and hemichannels in the spread of apoptosis as probed with Cbx and Cx mimetic peptides. (a and b) Effect of various inhibitors of GJs and hemichannels on the percentage of caspase-positive cells in areas 1 and $2,6 \mathrm{~h}$ after cyt $C$ loading. Fifteen minutes preincubation with $C b x$ before cyt $C$ loading followed by $6 \mathrm{~h}$ treatment thereafter $(15 \mathrm{~min}+6 \mathrm{~h})$ significantly reduced the Al in areas 1 and 2 in C6Cx43 - no effects were observed in C6WT cells. The same observations were made for $24 \mathrm{~h}+6 \mathrm{~h}$ Gap 27 . In contrast, $30 \mathrm{~min}+6 \mathrm{~h}$ Gap 26 or 27 did not reduce the $\mathrm{Al}$ in area 1 but significantly depressed it in area 2 . Concentrations are given in the text. (c and $\mathbf{d}$ ) Effect of $\mathrm{Cbx}$ on annexin V-positive counts in areas 1 and 2. The results are similar to the ones obtained with caspase stainings. (e) Effect of the various treatments on GJ coupling. Cbx and $24 \mathrm{~h}+6 \mathrm{~h}$ Gap 27 significantly inhibited dye coupling studied with FRAP. The inset shows SLDT experiments on C6Cx43 demonstrating that Cbx inhibition of GJ coupling is less potent in the presence of $10 \%$ serum (FBS). Experiments under serum-free conditions were performed as in the FRAP experiments to allow comparison. (f) Effect of the various treatments on DF-triggered ATP release. Cbx, Gap 26 and 27, applied in short or long incubation, all inhibited DF-triggered ATP release. The difference with panel $\mathrm{e}$ is that the $30 \mathrm{~min}$ or $30 \mathrm{~min}+6 \mathrm{~h}$ Gap $26 / 27$ did not inhibit GJ coupling. Graphs represent mean \pm S.E.M.; numbers on the bars indicate ' $n$ '; "significance compared to loading with DT-only (a-d) or to baseline (f); \# significance compared with the corresponding control condition; ${ }^{\$}$ significance compared with the corresponding

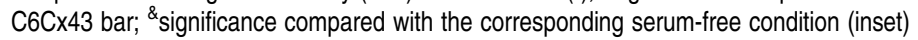



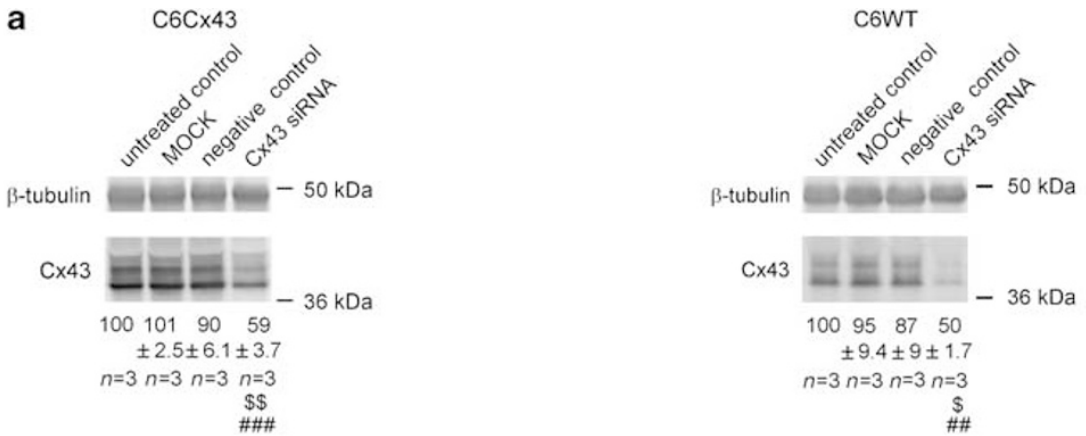
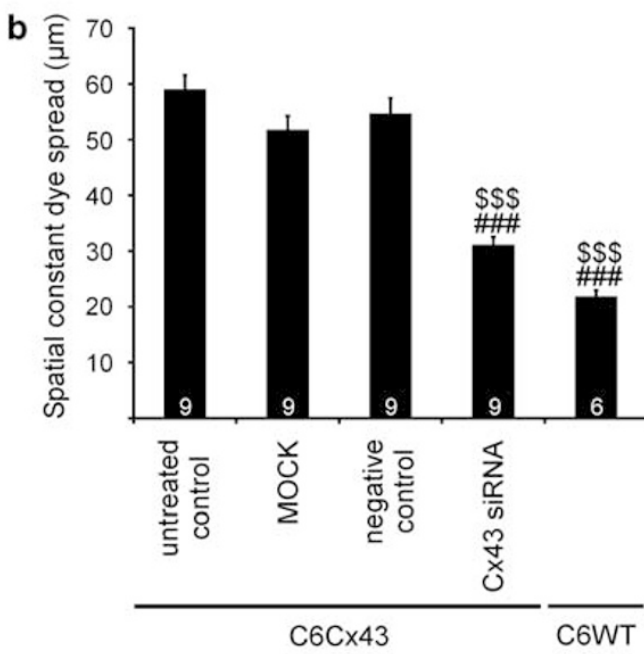

d

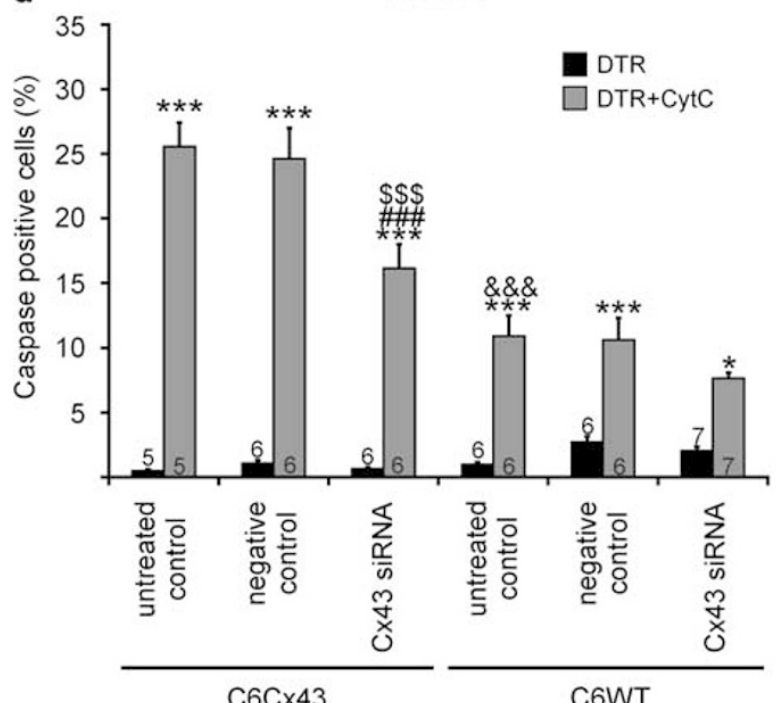

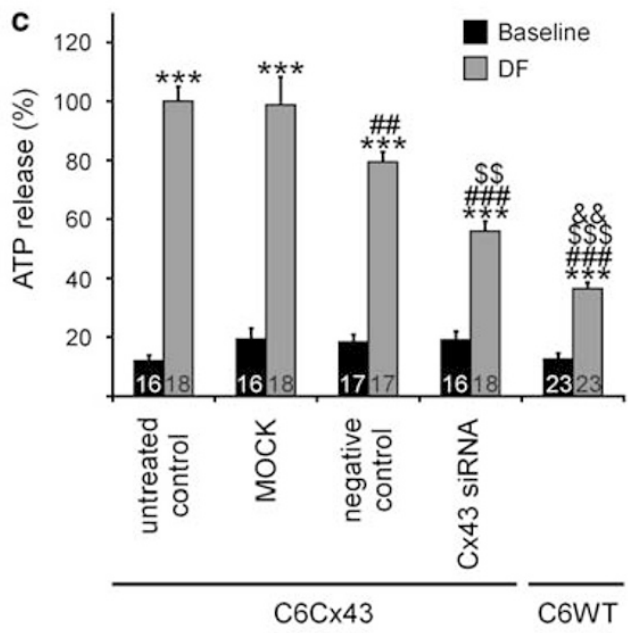

e

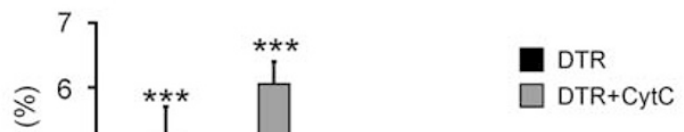

AREA 2

Figure 5 Role of GJs and hemichannels in the spread of apoptosis as probed with siRNA directed against Cx43. (a) siRNA treatment significantly decreased the expression of the $\mathrm{C} \times 43$ protein in $\mathrm{C} 6 \mathrm{C} \times 43$ and $\mathrm{C} 6 \mathrm{WT}$ cells. Expression level as a percentage of the untreated control $\pm \mathrm{S}$.E.M. ( $\beta$-tubulin reports equal loading). (b) siRNA treatment of $\mathrm{C} 6 \mathrm{Cx} 43$ cells significantly reduced GJ coupling investigated with SLDT - C6WT is given for comparison. (c) siRNA treatment of C6Cx43 significantly depressed DF-triggered ATP release. (d and e) siRNA treatment significantly decreased apoptosis in areas 1 and 2 in $\mathrm{C} 6 \mathrm{Cx} 43$ cells. Graphs represent mean \pm S.E.M.; numbers on the bars indicate ' $n$ '; *significance compared with baseline (c) and to loading with DTR-only (d-e); "significance compared with the corresponding bar of the untreated control; $\$$ significance compared with the corresponding bar of the negative control; ${ }^{\circledR}$ significance compared with the corresponding bar of Cx43 siRNA (c) or compared with the corresponding bar of the untreated control of $\mathrm{C} 6 \mathrm{C} \times 43$ ( $\mathbf{d}$ and $\mathbf{e})$

cannot be locally confined. In both scenarios, the hemichannels need to be opened in any case, a process that can be mediated by a list of conditions and intracellular signals mentioned in the introduction. We have reported in previous work that cytoplasmic $\mathrm{Ca}^{2+}$ changes may trigger hemichannel opening and that such $\mathrm{Ca}^{2+}$ dynamics may contribute 


\section{a}

\begin{tabular}{|c|c|c|c|c|c|}
\hline \multirow{2}{*}{$\begin{array}{l}\text { Inhibitor substance } \\
\text { or protocol }\end{array}$} & \multirow{2}{*}{$\begin{array}{l}\text { Incubation } \\
\text { scheme }\end{array}$} & \multicolumn{4}{|c|}{ Inhibition of } \\
\hline & & GJs & $\begin{array}{c}\text { hemichannel } \\
\text { responses }\end{array}$ & Al in area 1 & Al in area 2 \\
\hline $\begin{array}{l}\text { Cbx } \\
\text { Gap 26/27 } \\
\text { Gap 27 } \\
\text { siRNA }\end{array}$ & $\begin{array}{c}30 \min +6 h \\
24 h+6 h\end{array}$ & $\begin{array}{l}+ \\
+ \\
+\end{array}$ & $\begin{array}{l}+ \\
+ \\
+ \\
+\end{array}$ & $\begin{array}{l}+ \\
+ \\
+\end{array}$ & $\begin{array}{l}+ \\
+ \\
+ \\
+\end{array}$ \\
\hline
\end{tabular}

b

AREA 1

C

AREA 2
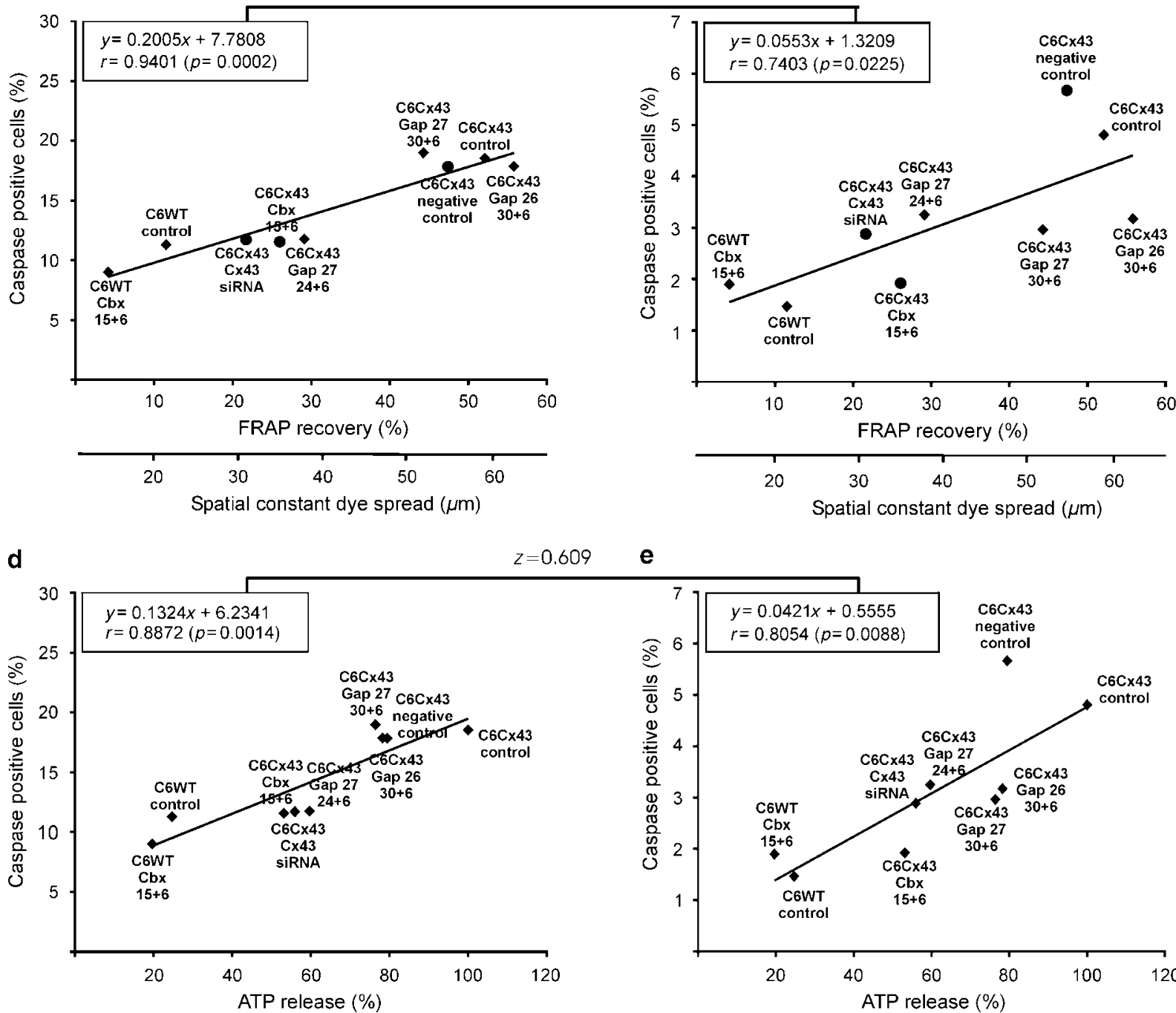

e

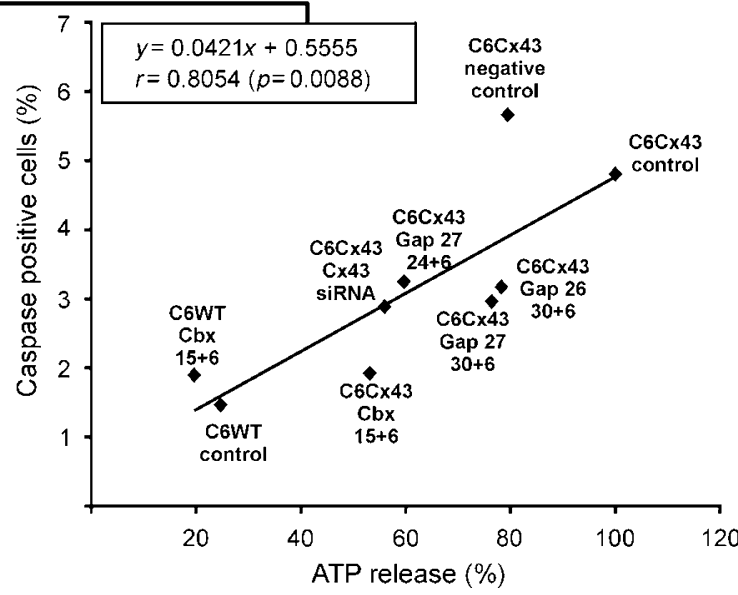

Figure 6 Relation between inhibition of $\mathrm{Cx}$ channel function and apoptosis spread. (a) Summary of the effects reported in Figures 4 and 5. Inhibitory effects are indicated by '+' signs. The pattern of inhibition of the Al in area 1 reflected the pattern of functional inhibition of GJs, whereas the Al pattern in area 2 paralleled the inhibition of hemichannels. (b-e) Correlation between GJ coupling ( $\mathbf{b}$ and $\mathbf{c}$ ) or hemichannel function (d and $\mathbf{e}$ ) and the Al in areas 1 and 2. Panels $b$ and $\mathbf{c}$ contain data from both FRAP $(\checkmark)$ and SLDT (-) experiments - coupling in C6WT and C6Cx43 under control conditions was used to match both scales (at the lower and upper end, respectively). Different incubation schemes are displayed: ' $15+6$ ' refers to $15 \mathrm{~min}+6 \mathrm{~h},{ }^{\prime} 30+6$ ' $-30 \mathrm{~min}+6 \mathrm{~h}$ and ' $24+6$ ' $-24 \mathrm{~h}+6 \mathrm{~h}$. The Pearson correlation coefficient ' $r$ ' was the largest and most significant for GJ coupling and Al in area 1 (b) whereas lowest in area 2 (c). The correlation coefficient was also significant for hemichannel ATP responses and Al in areas 1 and 2 (d and $\mathbf{e}$ ). Pair-wise comparison of ' $r$ ' in the two areas with the Fisher's $z$-test did not reveal significant differences

to ATP release triggered by DF conditions as well. ${ }^{9}$ This study confirms this finding, demonstrating the inhibition of ATP release by buffering cytoplasmic $\mathrm{Ca}^{2+}$ with BAPTA-AM. Apoptotic cell death is well known to be associated with changes in cytoplasmic $\mathrm{Ca}^{2+}, 2,22,33$ thereby offering a possible handle to hemichannel opening. In addition, mitochondrial $\mathrm{Ca}^{2+}$ increases may trigger cyt $C$ release, which is known to interact with $\mathrm{IP}_{3}$ receptors and thereby potentiates $\mathrm{Ca}^{2+}$ release from the stores and exacerbates mitochondrial $\mathrm{Ca}^{2+}$. driven cyt $C$ release in a vicious circle. ${ }^{39}$ cyt $C$ has too high a 
a
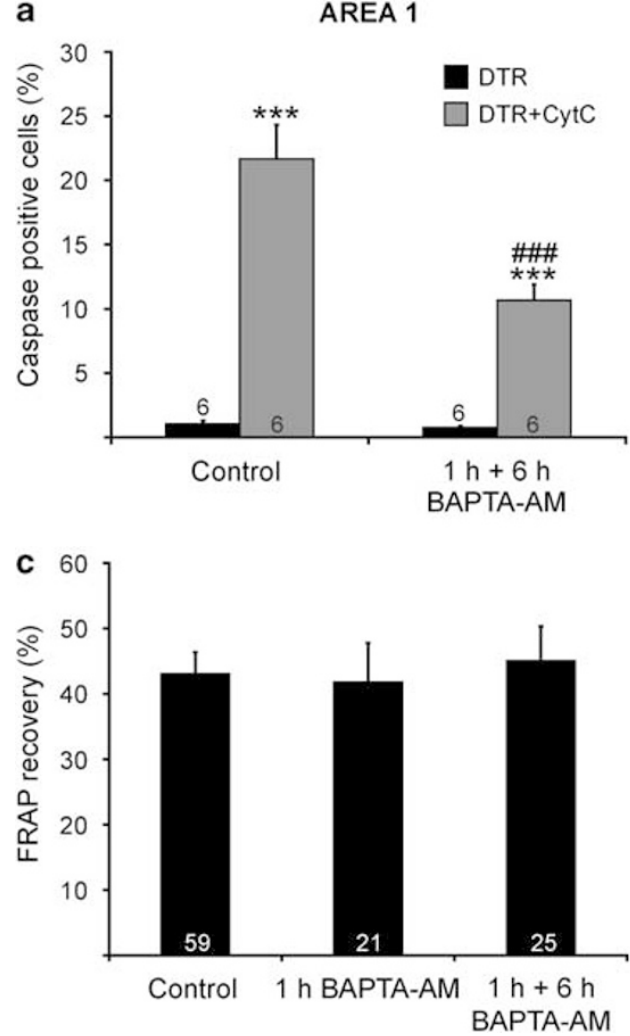
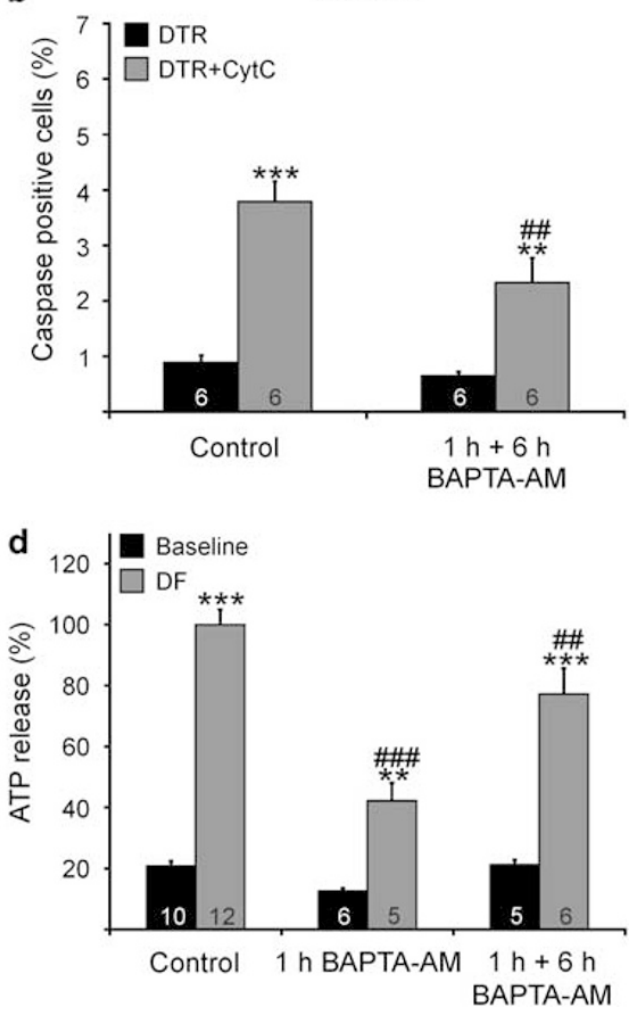

Figure 7 Role of cytoplasmic $\mathrm{Ca}^{2+}$ in apoptotic cell death in areas 1 and 2. (a and $\left.\mathbf{b}\right)$ Ester loading of $\mathrm{C} 6 \mathrm{C} \times 43$ cells with the intracellular $\mathrm{Ca}^{2+}$ chelator BAPTA-AM $1 \mathrm{~h}$ before cytC loading and continuation of this protocol $6 \mathrm{~h}$ thereafter significantly reduced the Al in areas 1 and 2. (c) BAPTA-AM treatment did not influence GJ coupling. (d) BAPTA-AM treatment reduced DF-triggered ATP responses. Graphs represent means \pm S.E.M.; numbers on the bars indicate ' $n$ '; *significance compared to loading with DTR-only (a-b) or baseline (d); " significance compared with the corresponding control condition

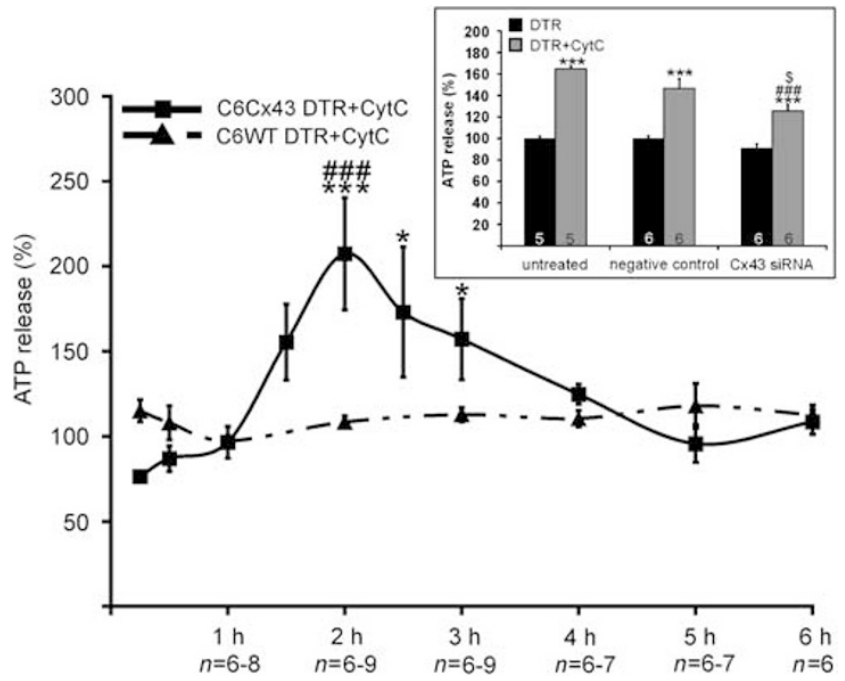

Figure 8 Extracellular ATP release after induction and spread of apoptosis. Extracellular ATP increased after cyt $C$ loading and attained a maximum $2 \mathrm{~h}$ later in C6Cx43 (ATP release expressed relative to DTR-only experiments not depicted). A flat trace was observed in C6WT cells. The 2-h peak was suppressed by siRNA treatment directed against gja1 (inset). Graphs represent means \pm S.E.M.; numbers beneath the graph indicate ' $n$ '; *significance compared to loading with DTR-only or baseline (inset); " significance compared with the corresponding WT data or the corresponding bar of the untreated control (inset); ${ }^{\$}$ significance compared with the corresponding bar of the negative control (inset) molecular weight $(12.4 \mathrm{kDa})$ to pass as a death messenger through GJs or hemichannels. However, the communication of $\mathrm{Ca}^{2+}$ signals between cells, either through $\mathrm{IP}_{3}$ moving through GJs $\left(\mathrm{Ca}^{2+}\right.$ may also pass under certain conditions $\left.{ }^{34}\right)$ or through paracrine ATP release, may well spark (and feed) the vicious $\mathrm{Ca}^{2+}$-cyt $C$ cycle, thereby spreading apoptosis. Interruption of the $\mathrm{Ca}^{2+}$ signal by buffering with BAPTA-AM clearly reduced apoptosis in the two areas. This experiment is, however, not conclusive in terms of the identity of the messenger, as $\mathrm{Ca}^{2+}$ may as well be involved in local intracellular apoptotic signaling (as opposed to contributing to the communication of apoptotic signals). ${ }^{33}$ In terms of the extracellular messengers released by apoptotic cells and acting on their healthy neighbors, the question is equally open. ATP and other messengers like glutamate have been well documented to leave the cell through hemichannels ${ }^{11,18,20}$ and their presence in excess may exert toxic effects through, for example, a rise in cytoplasmic $\mathrm{Ca}^{2+} .28,33$ However, in the presently used model, these two substances do not appear to be involved as paracrine messengers. Reactive oxygen species form another group of candidate molecules: they can be generated through effects of activated caspases on complex I and II in the electron transport chain and they can make their way into the cells through open hemichannels to trigger apoptosis. ${ }^{6,40}$ Admittedly, it may be difficult to pin down the messenger to a single substance and it is conceivable that a 
combination of factors is implied, a situation comparable to the spread of cell death through GJs where the responsible messenger(s) are still elusive.

In summary, our study indicates that hemichannels may, in concert with GJs, contribute to the spread of apoptosis from dying to healthy neighbors and even to remotely located cells. This does not rule out the 'good samaritan' effect of GJs that has been demonstrated for hemichannels as well. ${ }^{3,4,17,19} \mathrm{~A}$ balance may exist between the spread of survival and apoptotic factors, but due to the excessive cell death induced in the cyt $C$-loaded area, the balance is disrupted resulting in a domination of the apoptotic over the survival signals. In this case, the number seems to be relevant as many injured cells could result in a bad outcome for the healthy neighbors whereas many healthy neighbors could rescue a few injured cells. Our study demonstrates a proof-of-principle for the contribution of hemichannels in the spread of apoptotic signals in an in vitro expression system. Further study will be needed to identify the responsible molecular messengers and to verify these findings in ex vivo and in vivo model systems.

\section{Materials and Methods}

Cell culture. The following cell lines were used: $\mathrm{C} 6$ glioma cells, as wild-type (C6WT) cells, as stable transfectants with $\mathrm{Cx} 43$ (C6Cx43) or pannexin 1-Myc (C6Panx1-Myc), and human embryonic kidney (HEK)-293 cells stably transfected with $\mathrm{P}_{2} \mathrm{X}_{7}\left(\mathrm{HEK}-\mathrm{P}_{2} \mathrm{X}_{7}\right)$. C6 cells were cultured in DMEM and Ham's F12 (1:1) and HEK $-P_{2} X_{7}$ cells in DMEM, containing $10 \%$ fetal bovine serum (FBS), $100 \mathrm{U} / \mathrm{ml}$ penicillin, $100 \mu \mathrm{g} / \mathrm{ml}$ streptomycin, $0.250 \mu \mathrm{g} / \mathrm{ml}$ fungizone and $2 \mathrm{mM}$ glutamine (Gibco, Merelbeke, Belgium) at $37^{\circ} \mathrm{C}, 5 \% \mathrm{CO}_{2}$. Cell cultures were utilized up to passage number 20.

Agents. Dextran Texas Red (DTR, $10 \mathrm{kDa}$ ), Hoechst 33342, ethidium bromide (EtBr), propidium iodide (PI), carboxyfluorescein diacetate acetoxymethylester (CFDA-AM), 6-carboxyfluorescein (6-CF), Fluo-3-AM, 1,2-bis(2-aminophenoxy)ethane- $N, N, N^{\prime}, N^{\prime}$-tetraacetic acid acetoxymethyl ester (BAPTA-AM) and pluronic F-127 were purchased from Invitrogen (Merelbeke, Belgium). CytC from equine heart, 2',6'-diamidino-2-phenylindole (DAPI), probenecid, carbenoxolone (Cbx), apyrase (potato) grade $\mathrm{VI}$ and $\mathrm{VII}$, adenosine $5^{\prime}$-triphosphate disodium salt (ATP) and L-glutamic acid were obtained from Sigma (Bornem, Belgium). The Cx mimetic peptides Gap 27 (SRPTEKTIFII, amino acids 201-211 from the second extracellular loop of CX43) and Gap 26 (VCYDKSFPISHVR, amino acids 64-76 from the first extracellular loop of Cx43) were purchased from Sigma-Genosys (Cambridge, UK) and GenScript Corp (Piscataway, NJ, USA), respectively. The peptides were synthesized with a purity of 89 and $94.1 \%$, respectively.

Electroporation loading. Cells were grown to near confluency on 13-mm diameter glass coverslips or four-well plates (Nunc brand products, Roskilde, Denmark) depending on the apoptosis detection procedure. Electroporation was carried out as described before. ${ }^{25}$ Briefly, cell monolayer cultures were washed three times with Hanks' balanced salt solution buffered with Hepes (HBSS-Hepes) supplemented with glucose $\left(0.81 \mathrm{mM} \mathrm{MgSO}_{4} .7 \mathrm{H}_{2} \mathrm{O}, 0.95 \mathrm{mM} \mathrm{CaCl}_{2} .2 \mathrm{H}_{2} \mathrm{O}, 137 \mathrm{mM}\right.$ $\mathrm{NaCl}, 0.18 \mathrm{mM} \mathrm{Na}_{2} \mathrm{HPO}_{4} .2 \mathrm{H}_{2} \mathrm{O}, 5.36 \mathrm{mM} \mathrm{KCl}, 0.44 \mathrm{mM} \mathrm{KH}_{2} \mathrm{PO}_{4}, 5.55 \mathrm{mM}$ Dglucose, $25 \mathrm{mM}$ Hepes (pH 7.4)) and subsequently three times with a lowconductivity electroporation buffer $\left(4.02 \mathrm{mM} \mathrm{KH}_{2} \mathrm{PO}_{4}, 10.8 \mathrm{mM} \mathrm{K}_{2} \mathrm{HPO}_{4}, 1.0 \mathrm{mM}\right.$ $\mathrm{MgCl}_{2}, 300 \mathrm{mM}$ sorbitol, $2.0 \mathrm{mM}$ Hepes (pH 7.4)), placed underneath a two-wire PtIr electrode on the microscopic stage and electroporated in the presence of a tiny amount of electroporation buffer $(10 \mu \mathrm{l})$ containing $100 \mu \mathrm{M}$ cytC and $100 \mu \mathrm{M} 10 \mathrm{kDa}$ DTR. The $100 \mu \mathrm{M}$ cytC concentration was chosen based on dose-response experiments that demonstrated optimal spread of apoptosis to non-loaded cells. Lower $(10 \mu \mathrm{M})$ but also higher $(1 \mathrm{mM})$ concentrations gave less apoptosis at distance - the latter could be related to the faster progression of apoptosis (in the trigger zone) and, consequently, a more rapid loss of GJ communication. ${ }^{3,4,15}$ Control cultures were electroporated with a solution containing $100 \mu \mathrm{M}$ DTR-only. Electroporation was performed with $50 \mathrm{kHz}$ bipolar pulses applied as trains of 10 pulses of $2 \mathrm{~ms}$ duration each and repeated 15 times. The field strength was
$100 \mathrm{~V}$ peak-to-peak applied over a $400-\mu \mathrm{m}$ electrode separation distance. After electroporation, the cells were thoroughly washed with HBSS-Hepes and were then kept in $200 \mu$ l culture medium until scored for the apoptotic index (Al) with the various apoptosis detection assays described below.

The efficiency of electroporation loading was determined by measuring the fluorescence intensity from the 10-kDa DTR probe in the electroporation zone and dividing this value by the fluorescence intensity of a layer of DTR solution with a thickness equal to the cell thickness, as described previously. ${ }^{25}$ The loading efficiency was $27 \pm 1.77 \%$ in $\mathrm{C} 6 \mathrm{Cx} 43$ and $30 \pm 1.92 \%$ in the C6WT cultures $(n=7)$, meaning that the cyt $C$ concentration in the cells was in the order of 27 and $30 \mu \mathrm{M}$, respectively (both values not significantly different). Cell death in the electroporation zone, as evidenced by PI uptake, amounted to $0.8 \pm 0.2 \%$ of the cells $1 \mathrm{~h}$ after electroporation, which is not different from the value of $0.2 \pm 0.07 \%$ $(n=3)$ observed outside the electroporation zone or in cultures that did not receive electroporation treatment.

Apoptosis detection. Caspase-positive cells were detected by staining with $10 \mu \mathrm{M}$ of the CaspACE ${ }^{\mathrm{TM}}$ FITC-VAD-FMK In situ Marker from Promega (Promega Benelux, Leiden, The Netherlands) in HBSS-Hepes for $20 \mathrm{~min}$ at $37^{\circ} \mathrm{C}$. After fixing the cells with $4 \%$ paraformaldehyde (PFA) for $20 \mathrm{~min}$ at room temperature, nuclei were additionally stained for $5 \mathrm{~min}$ with $1 \mu \mathrm{g} / \mathrm{ml} \mathrm{DAPI}$ in phosphate-buffered saline supplemented with $\mathrm{Ca}^{2+}$ and $\mathrm{Mg}^{2+}(\mathrm{PBSD}+)$. Cells were mounted with Vectashield fluorescent mounting medium (VWR International, Leuven, Belgium) on glass slides

Stainings with annexin V-FITC, Hoechst 33342 and $\mathrm{EtBr}$ were combined in a single staining session and performed as follows: cells were rinsed twice with PBSD +, stained with annexin V-FITC (1:50 dilution; Roche Diagnostics, Penzberg, Germany), $2 \mu \mathrm{g} / \mathrm{ml}$ Hoechst 33342 and $2 \mu \mathrm{g} / \mathrm{ml} \mathrm{EtBr}$ in annexin V buffer ( $140 \mathrm{mM} \mathrm{NaCl}, 5 \mathrm{mM} \mathrm{CaCl}, 10 \mathrm{mM}$ Hepes (pH 7.4)) for $15 \mathrm{~min}$ at room temperature and rinsed another four times with PBSD +.

After staining, five images (in each culture) were taken in the zone adjacent to the cytC-loaded zone (three at one side, two at the other side) and another five taken one-image height $(370 \mu \mathrm{m})$ away (see Figure 1a) using a Nikon TE300 epifluorescence microscope equipped with a $\times 10$ objective (Plan APO, NA 0.45 - Nikon) and a Nikon DS-5M camera (Nikon Belux, Zaventem, Belgium). Images were also taken with a $\times 40$ oil immersion objective (S Fluor, NA $1.30-$ Nikon) for closer inspection of the apoptotic cells. The number of cells, positive for the concerned apoptotic marker, were counted in each image and expressed relative to the number of nuclei present and stated as the Al. Small groups of apoptotic bodies were counted as remnants of a single apoptotic cell. Analyses were carried out blinded and making use of custom-developed counting software.

Fluorescence recovery after photobleaching. Cells were seeded on $9.2 \mathrm{~cm}^{2}$ petri dishes (TPP, Trasadingen, Switzerland) and experiments were carried out at near confluency. Cells were loaded for $40 \mathrm{~min}$ at room temperature with the GJ-permeable fluorescent tracer CFDA-AM $(10 \mu \mathrm{M})$ in HBSS-Hepes. After extensive rinsing, cultures were transferred to the stage of a custom-made video-rate confocal laser scanning microscope. Fluorescence within a single cell was photobleached by a 1-s spot exposure to $488 \mathrm{~nm}$ Argon laser light, and dye influx from neighboring cells was recorded over the next 5 min with a $\times 40$ water immersion objective (Fluor, NA 0.8 - Nikon). At the end of the 5-min period, fluorescence in the bleached cell was expressed as the percentage of recovery relative to the starting level just before photobleaching, a measure of the degree of GJ dye coupling. The GJ blockers were included in the 40-min loading period and were also present during the measurements. Loading of CFDA-AM was not possible in the culture medium due to the presence of $10 \%$ FBS - therefore experiments were also performed with scrape loading and dye transfer (SLDT).

Scrape loading and dye transfer. Cells were seeded in four-well plates and grown to near confluency. They were then washed two times with nominally $\mathrm{Ca}^{2+}$-free SLDT buffer $\left(137 \mathrm{mM} \mathrm{NaCl}, 5.36 \mathrm{mM} \mathrm{KCl}, 0.81 \mathrm{mM} \mathrm{MgCl} 2.6 \mathrm{H}_{2} \mathrm{O}\right.$, $5.55 \mathrm{mM}$ D-glucose, $25 \mathrm{mM}$ Hepes (pH 7.4)), incubated for $1 \mathrm{~min}$ in SLDT buffer supplemented with the GJ-permeable tracer $6-\mathrm{CF}(400 \mu \mathrm{M})$ and a linear scratch was applied to the monolayer with a syringe needle. After $1 \mathrm{~min}$, the dye was washed away with HBSS-Hepes and the cells were left for $15 \mathrm{~min}$ to allow the reporter dye to spread between cells through GJs (all performed at room temperature). Images, 14 per well right next to the scrape, were acquired with a $\times 10$ objective and the microscope as described for apoptosis detection. Gap 
junctional communication was quantified by fitting the fluorescence diffusion profile in a direction away from the scrape, to a monoexponentially decaying function. A spatial constant of dye spread reflecting the degree of GJ coupling was determined with Prism software (Graphpad Software, San Diego, CA, USA). GJ channel blockers were also present during the 15 min period after the linear scratch was made. The experiments, shown as an inset to Figure $4 \mathrm{e}$, were performed to verify the effect of $\mathrm{Cbx}$ in the presence of $10 \% \mathrm{FBS}$ - in this case, serum was also present in the $15 \mathrm{~min}$ period after the scratch.

ATP measurements. ATP was measured using a luciferin/luciferase assay kit (product no. FL-AA; Sigma).

For extracellular measurements in the hemichannel assays of Figures $4 f$ and $5 c$, cells were seeded at 25000 cells per $\mathrm{cm}^{2}$ in 24-well plates (Falcon, Becton Dickinson, Erembodegem, Belgium) and experiments were carried out the next day (as described in ${ }^{8,9} \mathrm{De}$ Vuyst et al.). Cells were washed with divalent-free (DF) buffer (137 mM NaCl, $0.18 \mathrm{mM} \mathrm{Na}_{2} \mathrm{HPO}_{4} .2 \mathrm{H}_{2} \mathrm{O}, 5.36 \mathrm{mM} \mathrm{KCl}, 0.44 \mathrm{mM} \mathrm{KH}_{2} \mathrm{PO}_{4}, 4.0 \mathrm{mM}$ EGTA, $5.55 \mathrm{mM}$ D-glucose, $25 \mathrm{mM}$ Hepes (pH 7.4)) and then incubated for $2.5 \mathrm{~min}$ in $150 \mu$ l of the same buffer. For baseline measurements, DF buffer was replaced by HBSS-Hepes - all manipulations were performed at room temperature. At the end of the 2.5 min period, $75 \mu$ l of ATP assay mix in HBSS-Hepes (1:5) was added and luminescence was measured with a plate reader (Victor-3, type 1420; Perkin Elmer, Brussels, Belgium). ATP release was expressed as a percentage of DF-triggered ATP release triggered under control (vehicle) conditions (100\%) for all experiments performed on the same day. An ATP calibration curve was constructed in the range of 0 (no added ATP) to $1 \mu \mathrm{M}$ ATP. C6Cx43 cells released $17 \pm 1.3 \mathrm{nM}$ ATP in baseline and $310 \pm 43 \mathrm{nM}$ upon DF exposure (in a $225 \mu \mathrm{l}$ volume $-n=85$ ). ATP release after cyt $C$ loading (Figure 8 ) was determined as follows: $75 \mu$ lof ATP assay mix in HBSS-Hepes $(1: 5)$ was added to $200 \mu$ l of culture medium above the cells and luminescence was measured, all as described above. ATP release was expressed relative to control cultures loaded with DTR-only (100\%) for all experiments performed on the same day. The peak at $2 \mathrm{~h}$ in Figure 8 corresponds to $210 \pm 29 \mathrm{nM}$ ATP whereas the corresponding time point in DTR-only cultures gave $92 \pm 13$ nM ATP (in a $275 \mu$ l volume $-n=9$ ).

Intracellular ATP was measured $2 \mathrm{~h}$ after cytC loading as follows: cells were washed three times with ice-cold PBSD + and lysed in $50 \mu \mathrm{l}$ of $1 \times$ Somatic cell ATP releasing reagent (Sigma). The lysates were boiled for 5 min followed by a centrifugation step for $5 \mathrm{~min}$ at 14000 r.p.m. ATP assay mix $(190 \mu \mathrm{l})$ in HBSSHepes $(1: 25)$ was added to $10 \mu \mathrm{l}$ of the supernatants and luminescence was measured with the plate reader. An ATP calibration curve was constructed in the range of $0-1.81 \mu \mathrm{M}$ ATP. Intracellular ATP content was normalized for the amount of protein present in the supernatants as measured by the Bio-Rad DC protein assay kit (Bio-Rad, Nazareth, Belgium) and expressed as a percentage of intracellular ATP content of cultures loaded with DTR only (100\%).

$\mathrm{Ca}^{2+}$ imaging. Cells were seeded on glass bottom microwells (MatTek Corporation, Ashwood, MA, USA) and ester loaded for 30 min with $5 \mu \mathrm{M}$ Fluo-3-AM in HBSS-Hepes supplemented with $1 \mathrm{mM}$ of probenecid and $0.01 \%$ pluronic $\mathrm{F}-127$ at $37^{\circ} \mathrm{C}$, followed by a de-esterification over $15 \mathrm{~min}$. Imaging was performed using an inverted fluorescence microscope equipped with a $\times 40$ oil immersion objective and an intensified CCD camera (Extended Isis camera; Photonic Science, East Sussex, UK). Cells were superfused for 1 min with HBSS-Hepes followed by 1 min with $400 \mathrm{nM}$ of ATP and an additional 2 min with HBSS-Hepes on the stage of the microscope. Images were generated with software written in Microsoft Visual $C^{++}$ 6.0, after standard background and shade-correction procedures.

Immunocytochemistry. Cells on coverslips were fixed for 20 min with $4 \%$ PFA and permeabilized for $10 \mathrm{~min}$ with $0.2 \%$ Triton $X-100$. Cells were immunolabeled for at least $1 \mathrm{~h}$ with mouse anti-cytC antibody directed against horse cytC (clone 3A3.C2, 1/1000 dilution in PBSD + with $0.4 \%$ gelatin) that does not cross-react with rat cytC, kindly provided by Dr. Jemmerson (Department of Microbiology, the University of Minnesota Medical School, Minneapolis, MN, USA), ${ }^{26}$ and subsequently incubated for another hour with secondary Alexa 488conjugated goat anti-mouse IgG (1/1000 dilution; Sigma). The nuclei were stained with $1 \mu \mathrm{g} / \mathrm{ml} \mathrm{DAPI}$ in PBSD + for $5 \mathrm{~min}$ and cells were mounted with Vectashield fluorescent mounting medium onto glass slides. All steps were carried out at room temperature and cell cultures were rinsed thoroughly with PBSD + between all incubation steps. Samples were examined and photographed with the microscope as described for apoptosis detection.
Western blotting. Cells were seeded in $75 \mathrm{~cm}^{2}$ falcons or $9.2 \mathrm{~cm}^{2}$ petri dishes. Total cell protein lysates were extracted in ice-cold radioimmuno precipitation assay buffer and sonicated five times for $10 \mathrm{~s}$. Separation of Triton X-100 soluble and insoluble fractions was performed according to a protocol described earlier. ${ }^{8}$ Protein concentrations were determined using a Bio-Rad DC protein assay kit. Protein lysates $(100 \mu \mathrm{g})$ were separated on a $10 \%$ Bis-Tris gel and subsequently transferred onto a nitrocellulose membrane (Amersham Pharmacia Biotech, Buckinghamshire, UK). Membranes were blocked with $5 \%$ non-fat milk in Trisbuffered saline containing $0.1 \%$ Tween 20 and probed with a rabbit anti-Cx43 antibody (1/10000 dilution; Sigma) or a polyclonal rabbit anti-rat $P_{2} X_{7}$ antibody (1/ 1000 dilution; Alomone Labs, Jerusalem, Israel) followed by secondary alkaline phosphatase-conjugated goat anti-rabbit IgG antibody (1/8000 dilution; Sigma). Detection was carried out using the BCIP/NBT kit (Zymed, Invitrogen) according to the manufacturer's instructions. As a loading control, the membranes were immunoblotted for rabbit anti- $\beta$-tubulin antibody (1/1000; Abcam, Cambridge, UK) or total protein staining was carried out with SYPRO Ruby protein blot dye (Invitrogen, Molecular Probes). Protein expression was quantified using ImageJ software. After correcting the background, the integrated density of each protein band was measured using the same selection surface for each measurement.

RT-PCR. Cells were seeded in $75 \mathrm{~cm}^{2}$ falcons and harvested in ice-cold PBSD +. Total RNA was isolated using the SV Total RNA isolation system kit (Promega) according to the manufacturer's instructions and samples were subsequently subjected to DNase treatment (Ambion, Austin, TX, USA). Reverse transcription of $3 \mu \mathrm{g}$ of total RNA was performed with the iScript cDNA synthesis kit (Bio-Rad). The cDNA was amplified using the iTaq DNA polymerase kit (Bio-Rad) and $25 \mathrm{pmol}$ of the following primers in a final volume of $50 \mu \mathrm{l}$ : Panx1 forward primer, 5'-TTCTTCCCCTACATCCTGCT-3' and Panx1 reverse primer, 5'-GGTCCATCTCTCAGGTCCAA-3' (Invitrogen); glyceraldehyde 3-phosphate dehydrogenase (GAPDH) forward primer, 5'-ACCACAGTCCATGCCATCAC-3 and GAPDH reverse primer, $5^{\prime}$-TCCACCACCCTGTTGCTGTA-3' (Eurogentec, Seraing, Belgium). The following PCR protocol was applied: 35 cycles for Panx1 (45 s $94^{\circ} \mathrm{C}, 60 \mathrm{~s} 50^{\circ} \mathrm{C}$ and $60 \mathrm{~s} 72^{\circ} \mathrm{C}$ ) and $30 \mathrm{cycles}$ for GAPDH $\left(60 \mathrm{~s} 95^{\circ} \mathrm{C}, 60 \mathrm{~s}\right.$ $52.7^{\circ} \mathrm{C}$ and $60 \mathrm{~s} 72^{\circ} \mathrm{C}$ ), each followed by a final extension for $7 \mathrm{~min}$ at $72^{\circ} \mathrm{C}$. The samples were separated on a $1.8 \% \mathrm{w} / \mathrm{v}$ EtBr-stained agarose gel. As an internal control, GAPDH was detected and as a negative control, reverse transcriptase was replaced with RNase/DNase-free water in the C6Panx1-Myc sample.

siRNA treatment. All reagents used here were obtained from Dharmacon (Thermo Fisher Scientific, Erembodegem, Belgium). $\mathrm{C} 6 \mathrm{C} \times 43$ and C6WT cells were seeded at 37500 and 36250 cells per $\mathrm{cm}^{2}$, respectively, and transfected $24 \mathrm{~h}$ later with Dharmafect 1 lipid reagent and $125 \mathrm{nM}$ of siGENOME ON-TARGETplus SMARTpool siRNA, which contains four different siRNA duplexes directed against rat gja1 (sense strand sequences: siRNA no. 1: 5'-CAACAACCUGGCUGC GAAAUU-3'; siRNA no. 2: 5'-UGAUUGAAAUGUCGAGUUAUU-3'; siRNA no. 3: 5'-CGUGAAGGGAAGAAGCGA-UUU-3'; siRNA no. 4: 5'-UUACUGAGAUUCUGC GAUAUU- $3^{\prime}$ ). Culture medium was refreshed after $24 \mathrm{~h}$ and experiments were carried out $48 \mathrm{~h}$ after transfection, that is $72 \mathrm{~h}$ after seeding. Transfection efficiency was determined with the siGLO transfection indicator and averaged $84 \pm 2.2 \%$ $(n=6)$ for $\mathrm{C} 6 \mathrm{C} \times 43$ and $90 \pm 2.7 \%(n=6)$ for C6WT. Various control conditions were used, including untreated control cultures, MOCK-treated cultures exposed to the lipid reagent without siRNA and cultures treated with a non-targeting negative control (ON-TARGETplus siCONTROL non-targeting pool). The latter contains a pool of four non-targeting siRNAs, confirmed to have minimal targeting of known rat genes.

Data and statistical analyses. Data are expressed as mean \pm S.E.M., with ' $n$ ' denoting the number of independent experiments. In the fluorescence recovery after photobleaching (FRAP) experiments, ' $n$ ' indicates the number of cells bleached (in two to three different cultures for each condition). Multiple groups were compared by one-way ANOVA and a Bonferroni post-test, using GraphPad Instat software (Graphpad Software). The Pearson coefficients $(r)$ of the correlations depicted in Figure 6 were tested for their significance compared with zero using a Student's $t$-test with a two-tailed $P$-value and compared among each other with a Fisher's $z$-test. $P<0.05$ or $z>1.96$ was considered statistically significant. Statistical significance is indicated in the graphs by one symbol for $P<0.05$, two symbols for $P<0.01$ and three symbols for $P<0.001$. 
Acknowledgements. We gratefully acknowledge Dr. Ronald Jemmerson fo supplying anti-cytC antibodies and Dr. Dubyak for the HEK- $\mathrm{P}_{2} \mathrm{X}_{7}$ cells. This study was impossible without the valuable help of Mr. Timothy Voorspoels, for developing analysis tools and software, and Mr. Eric Tack for technical assistance. Our study is supported by the Fund for Scientific Research Flanders (FWO-Vlaanderen), Belgium (grant nos. G.0354.07 and G.0140.08 to LL) and the Interuniversity Attraction Poles Program (Belgian Science Policy, project P6/31). ED is a doctoral research fellow of the FWO-Vlaanderen.

1. Cusato K, Bosco A, Rozental R, Guimaraes CA, Reese BE, Linden R et al. Gap junction mediate bystander cell death in developing retina. J Neurosci 2003; 23: 6413-6422.

2. Krutovskikh VA, Piccoli C, Yamasaki H. Gap junction intercellular communication propagates cell death in cancerous cells. Oncogene 2002; 21: 1989-1999.

3. Krysko DV, Leybaert L, Vandenabeele P, D'Herde K. Gap junctions and the propagation of cell survival and cell death signals. Apoptosis 2005; 10: 459-469.

4. Vinken M, Vanhaecke T, Papeleu P, Snykers S, Henkens T, Rogiers V. Connexins and their channels in cell growth and cell death. Cell Signal 2006; 18: 592-600.

5. Evans WH, De Vuyst E, Leybaert L. The gap junction cellular internet: connexin hemichannels enter the signalling limelight. Biochem J 2006; 397: 1-14.

6. Ramachandran S, Xie LH, John SA, Subramaniam S, Lal R. A novel role for connexin hemichannel in oxidative stress and smoking-induced cell injury. PLOS ONE 2007; 2: e712.

7. Retamal MA, Schalper KA, Shoji KF, Bennett MV, Saez JC. Opening of connexin 43 hemichannels is increased by lowering intracellular redox potential. Proc Natl Acad Sci USA 2007; 104: 8322-8327.

8. De Vuyst E, Decrock E, De Bock M, Yamasaki H, Naus CC, Evans WH et al. Connexin hemichannels and gap junction channels are differentially influenced by lipopolysaccharide and basic fibroblast growth factor. Mol Biol Cell 2007; 18: 34-46.

9. De Vuyst E, Decrock E, Cabooter L, Dubyak GR, Naus CC, Evans WH et al. Intracellula calcium changes trigger connexin 32 hemichannel opening. EMBO J 2006; 25: 34-44.

10. Thimm J, Mechler A, Lin H, Rhee S, Lal R. Calcium-dependent open/closed conformations and interfacial energy maps of reconstituted hemichannels. J Biol Chem 2005; 280: 10646-10654.

11. Gomes P, Srinivas SP, Van Driessche W, Vereecke J, Himpens B. ATP release through connexin hemichannels in corneal endothelial cells. Invest Ophthalmol Vis Sci 2005; 46 : 1208-1218.

12. Thompson RJ, Zhou N, MacVicar BA. Ischemia opens neuronal gap junction hemichannels. Science 2006; 312: 924-927.

13. Li F, Sugishita K, Su Z, Ueda I, Barry WH. Activation of connexin-43 hemichannels can elevate $[\mathrm{Ca}(2+)] \mathrm{i}$ and $[\mathrm{Na}(+)] \mathrm{i}$ in rabbit ventricular myocytes during metabolic inhibition. J Mol Cell Cardiol 2001; 33: 2145-2155.

14. Stong BC, Chang $\mathrm{Q}$, Ahmad S, Lin X. A novel mechanism for connexin 26 mutation linked deafness: cell death caused by leaky gap junction hemichannels. Laryngoscope 2006; 116: 2205-2210.

15. Kalvelyte A, Imbrasaite A, Bukauskiene A, Verselis VK, Bukauskas FF. Connexins and apoptotic transformation. Biochem Pharmacol 2003; 66: 1661-1672.

16. Stridh MH, Tranberg M, Weber SG, Blomstrand F, Sandberg M. Stimulated efflux of amino acids and glutathione from cultured hippocampal slices by omission of extracellula calcium: likely involvement of connexin hemichannels. J Biol Chem 2008; 283: 10347-10356.

17. Rodriguez-Sinovas A, Cabestrero A, Lopez D, Torre I, Morente M, Abellan A et al. The modulatory effects of connexin 43 on cell death/survival beyond cell coupling. Prog Biophys Mol Biol 2007; 94: 219-232
18. Takeuchi $\mathrm{H}$, Jin S, Wang J, Zhang G, Kawanokuchi J, Kuno $\mathrm{R}$ et al. Tumor necrosis factoralpha induces neurotoxicity via glutamate release from hemichannels of activated microglia in an autocrine manner. J Biol Chem 2006; 281: 21362-21368.

19. Plotkin $\mathrm{LI}$, Manolagas SC, Bellido T. Transduction of cell survival signals by connexin-43 hemichannels. J Biol Chem 2002; 277: 8648-8657.

20. Kang J, Kang N, Lovatt D, Torres A, Zhao Z, Lin J et al. Connexin 43 hemichannels are permeable to ATP. J Neurosci 2008; 28: 4702-4711.

21. Saraste A, Pulkki K. Morphologic and biochemical hallmarks of apoptosis. Cardiovasc Res 2000; 45: 528-537.

22. Cusato K, Ripps H, Zakevicius J, Spray DC. Gap junctions remain open during cytochrome c-induced cell death: relationship of conductance to 'bystander' cell killing. Cell Death Differ 2006; 13: 1707-1714.

23. Udawatte $\mathrm{C}$, Ripps $\mathrm{H}$. The spread of apoptosis through gap-junctional channels in BHK cells transfected with Cx32. Apoptosis 2005; 10: 1019-1029.

24. Frank DK, Szymkowiak B, Josifovska-Chopra O, Nakashima T, Kinnally KW. Single-cell microinjection of cytochrome $c$ can result in gap junction-mediated apoptotic cell death of bystander cells in head and neck cancer. Head Neck 2005; 27: 794-800.

25. De Vuyst E, De Bock M, Decrock E, Van Moorhem M, Naus C, Mabilde C et al. In situ bipolar electroporation for localized cell loading with reporter dyes and investigating gap junctional coupling. Biophys J 2008; 94: 469-479.

26. Goshorn SC, Retzel E, Jemmerson R. Common structural features among monoclonal antibodies binding the same antigenic region of cytochrome c. J Biol Chem 1991; 266: 2134-2142

27. Sanson M, Marcaud V, Robin E, Valery C, Sturtz F, Zalc B. Connexin 43-mediated bystander effect in two rat glioma cell models. Cancer Gene Ther 2002; 9: 149-155.

28. Franke H, Krugel U, Illes P. P2 receptors and neuronal injury. Pflugers Arch 2006; 452: 622-644.

29. Shestopalov VI, Panchin Y. Pannexins and gap junction protein diversity. Cell Mol Life Sci 2008; 65: 376-394.

30. Locovei S, Scemes E, Qiu F, Spray DC, Dahl G. Pannexin1 is part of the pore forming unit of the P2X(7) receptor death complex. FEBS Lett 2007; 581: 483-488.

31. Lai CP, Bechberger JF, Thompson RJ, MacVicar BA, Bruzzone R, Naus CC. Tumorsuppressive effects of pannexin 1 in C6 glioma cells. Cancer Res 2007; 67: 1545-1554.

32. Guo Y, Martinez-Williams C, Gilbert KA, Rannels DE. Inhibition of gap junction communication in alveolar epithelial cells by 18alpha-glycyrrhetinic acid. Am J Physiol 1999; 276: L1018-L1026.

33. Orrenius S, Zhivotovsky B, Nicotera P. Regulation of cell death: the calcium-apoptosis link. Nat Rev Mol Cell Biol 2003; 4: 552-565.

34. Dupont G, Combettes L, Leybaert L. Calcium dynamics: spatio-temporal organization from the subcellular to the organ level. Int Rev Cytol 2007; 261: 193-245.

35. Liu F, Arce FT, Ramachandran S, Lal R. Nanomechanics of hemichannel conformations: connexin flexibility underlying channel opening and closing. J Biol Chem 2006; 281: 23207-23217

36. Romanov RA, Rogachevskaja OA, Bystrova MF, Jiang P, Margolskee RF, Kolesnikov SS Afferent neurotransmission mediated by hemichannels in mammalian taste cells. EMBO J 2007; 26: 657-667.

37. Pearson RA, Luneborg NL, Becker DL, Mobbs P. Gap junctions modulate interkinetic nuclear movement in retinal progenitor cells. J Neurosci 2005; 25: 10803-10814.

38. Spray DC, Ye ZC, Ransom BR. Functional connexin 'hemichannels': a critical appraisal. Glia 2006; 54: 758-773.

39. Boehning D, Patterson RL, Snyder SH. Apoptosis and calcium: new roles for cytochrome c and inositol 1,4,5-trisphosphate. Cell Cycle 2004; 3: 252-254.

40. Ricci JE, Gottlieb RA, Green DR. Caspase-mediated loss of mitochondrial function and generation of reactive oxygen species during apoptosis. J Cell Biol 2003; 160: 65-75. 